\title{
The Mammalian Cytosolic Type 2 (R)- $\beta$-hydroxybutyrate Dehydrogenase (BDH2) is 4-oxo-L-proline Reductase (EC 1.1.1.104)
}

Sebastian P. Kwiatkowski ${ }^{1}$, Maria Bozko ${ }^{1}$, Michal Zarod ${ }^{1}$, Apolonia Witecka ${ }^{1}$, Adam K. Jagielski ${ }^{1}$, and Jakub Drozak ${ }^{1 *}$

${ }^{1}$ Department of Metabolic Regulation, Institute of Biochemistry, Faculty of Biology, University of Warsaw, Miecznikowa 1, 02-096 Warsaw, Poland

*Corresponding author: Jakub Drozak

E-mail: jdrozak@biol.uw.edu.pl

Running title: Molecular identification of 4-oxo-L-proline reductase

Keywords: 4-oxo-L-proline, cis-4-oxo-L-proline, trans-4-oxo-L-proline, SDR superfamily, BDH2, DHRS6, 4-oxo-L-proline reductase, 


\section{Abstract}

The early studies on chicken embryos revealed that exposition to 4-oxo-L-proline resulted in the explicit increase in 4-hydroxy-L-proline content in their tissues. In 1962, 4-oxo-L-proline reductase, an enzyme responsible for the reduction of 4-oxo-Lproline, was partially purified from rabbit kidneys and characterized biochemically, but only recently the molecular identity of the enzyme has been unveiled in our laboratory. The present investigation reports the purification, identification as well as biochemical characterization of 4-oxo-Lproline reductase. The enzyme was purified from rat kidneys about 280-fold. Following mass spectrometry analysis of the purified protein preparation, the mammalian cytosolic type $2(\mathrm{R})-\beta$ hydroxybutyrate dehydrogenase (BDH2) emerged as the only meaningful candidate for the reductase. Rat and human BDH2 were expressed in E. coli, purified, and shown to catalyze the reversible reduction of 4-oxo-L-proline to cis-4-hydroxy-Lproline, as confirmed by chromatographic and mass spectrometry analysis. Specificity studies carried out on both enzymes showed that 4-oxo-L-proline was the best substrate, particularly the human enzyme acted with 9400-fold higher catalytic efficiencies on 4-oxo-L-proline than on (R)- $\beta$ hydroxybutyrate. Finally, HEK293T cells efficiently metabolized 4-oxo-L-proline to cis-4hydroxy-L-proline and simultaneously accumulated trans-4-hydroxy-L-proline in the culture medium, suggesting that 4-oxo-L-proline is most likely an inhibitor of trans-4-hydroxy-Lproline metabolism in human cells. We conclude that $\mathrm{BDH} 2$ is mammalian 4-oxo-L-proline reductase that converts 4-oxo-L-proline to cis-4hydroxy-L-proline, and not to trans-4-hydroxy-Lproline as currently thought, and hypothesize that the enzyme may be considered as a potential source of cis-4-hydroxy-L-proline in mammalian tissues.

\section{Introduction}

4-oxo-L-proline is a poorly studied derivative of Lproline (Fig. 1). Although the only known natural source of this compound is antibiotic X-type actinomycin produced by Streptomyces antibioticus (1), 4-oxo-L-proline has been occasionally detected in various biological samples, including extracts of human embryonic kidney 293 cells (HEK293T) (2) as well as the blood samples of type 2 diabetes patients treated with metformin, sulphonylurea or both drugs combined (3). Unfortunately, the exact source and metabolic routes of 4-oxo-L-proline in vivo have never been addressed appropriately and our knowledge of its physiological significance is still sparse. Interestingly, in the late 1950s, Mitoma and coworkers (4) showed that the administration of 4oxo-L-proline to chick embryos increased the free 4-hydroxy-L-proline content in their tissues, suggesting that 4-oxo-L-proline might be enzymatically reduced in vivo. Later, 4-oxo-Lproline reductase (EC 1.1.1.104), a cytosolic enzyme converting 4-oxo-L-proline into 4hydroxy-L-proline at the expense of NADH oxidation ( $c f$. Fig. 1), was partially purified from rabbit kidney and characterized (5), but its molecular identity and biochemical properties have remained unknown so far.

In the current work, we report the identification of mammalian 4-oxo-L-proline reductase (EC 1.1.1.104) as 3-hydroxybutyrate dehydrogenase type 2 (BDH2, DHRS6, Fig. 2), which was previously suggested to act as a cytosolic (R)- $\beta$-hydroxybutyrate dehydrogenase involved in ketone body utilization (6) or to catalyze the synthesis of 2,5-dihydroxybenzoic acid (2,5-DHBA, gentisic acid), a putative mammalian siderophore (7). We provide a biochemical characterization of this enzyme and show that it catalyzes the reversible conversion of 4-oxo-Lproline to cis-4-hydroxy-L-proline, with favorable substrate specificity and catalytic efficiency. BDH2 is therefore the first mammalian enzyme capable of yielding cis-4-hydroxy-L-proline, a metabolite thought to only be of exogenous origin. We also reveal that HEK293T cells efficiently metabolize 4oxo-L-proline to cis-4-hydroxy-L-proline, indicating that the activity of $\mathrm{BDH} 2$ might be considered as a potential source of cis-4-hydroxyL-proline in mammalian tissues. However, the 
physiological importance of these findings remains unclear.

\section{Results}

\section{Purification and identification of rat 4-oxo-L- proline reductase}

Through the purification process, 4-oxo-L-proline reductase was assayed spectrophotometrically by measuring the rate of 4-oxo-L-proline reduction with concomitant oxidation of NADH to NAD ${ }^{+}$. The enzyme was purified from rat kidneys about 280 -fold by a three-step procedure of column chromatography involving anion-exchange chromatography on Q Sepharose FF resin, affinity chromatography on HiScreen Blue FF column and gel filtration on Superdex 200 16/60 HiLoad column (Fig. 3). Only one enzyme species was present throughout the purification process as indicated by a single activity peak at each purification step. The yield of the purification was $25 \%$. For details on the purification refer to Table 1 .

SDS-PAGE analysis revealed three polypeptides of about 90,70 , and $25 \mathrm{kDa}$ ( $c f$. Fig. 3D) that coeluted with the enzyme activity in the fractions derived from the Superdex 200 purification step. All three bands were excised from the gel, digested with trypsin, and obtained peptides were analyzed by tandem mass spectrometry (QTOF). The sequences of the identified peptides were then compared with the rat reference proteome from the NCBI Protein database (Table 2). Surprisingly, the analysis indicated a lack of any proteins of unknown function. However, a thorough analysis of the available research data on the identified proteins allowed us to hypothesize that 3-hydroxybutyrate dehydrogenase type 2 (BDH2) protein might be a sought 4-oxo-L-proline reductase. $\mathrm{BDH} 2$ was present as a predominant protein in band $\mathrm{C}$ and was the only cytosolic dehydrogenase identified in analyzed protein bands. Twenty-six peptide sequences from the rat BDH2 (underlined in Fig. 2) were found in the mass spectrometry analysis to cover about $54 \%$ of its sequence. To exclude the possibility of missing any potential reductases due to poor extraction of tryptic peptides from the polyacrylamide gel we performed the tandem mass spectrometry identification of all proteins present in the most active fractions from the Superdex 200 purification step (F28 and F29, $c f$. Table 2). Again, $\mathrm{BDH} 2$ was found as the only reasonable candidate for the rat 4-oxo-L-proline reductase.

\section{Human and rat $\mathrm{BDH} 2$ catalyze the reversible reduction of 4-oxo-L-proline to cis-4-hydroxy-L- proline}

To verify the accuracy of the molecular identification of rat $\mathrm{BDH} 2$ as 4-oxo-L-proline reductase as well as to compare the activity of the rat and human enzymes, both proteins were overexpressed as fusion proteins with the $N$ terminal His 6 tag in a bacterial expression system, purified (Fig. 4) and shown to catalyze the reduction of 4-oxo-L-proline in the presence of NADH (Fig. 5). To further confirm that observed activity resulted from $\mathrm{BDH} 2$, and not from impurities that might co-purify with the recombinant proteins, mutated forms of both orthologues, Y157F and Y147F for rat and human, respectively, were prepared and shown to be catalytically inactive with 4-oxo-L-proline and NADH as substrates ( $c f$. Fig. 2, and Fig. 5). Those results indicate that $\mathrm{BDH} 2$ possesses the activity of 4-oxo-L-proline reductase (EC 1.1.1.104).

Due to the high amino acid sequence and structural similarities to various bacterial hydroxybutyrate dehydrogenases, $\mathrm{BDH} 2$ was previously shown to be involved in the ketone body (R)- $\beta$-hydroxybutyrate metabolism

Furthermore, BDH2 has also been proposed to catalyze the synthesis of 2,5-dihydrobenzoic acid (2,5-DHBA, gentisic acid), putative mammalian siderophore (7). These reports led us to verify the substrate specificity of $\mathrm{BDH} 2$, including (R)- $\beta$ hydroxybutyrate, two isomers of 4-hydroxy-Lproline (oxidation) as well as 5-oxo-L-proline (Lpyroglutamic acid), and acetoacetate (reduction), the latter as a product of postulated (R)- $\beta$ hydroxybutyrate dehydrogenase activity of $\mathrm{BDH} 2$. We tested neither 3,6-dihydroxy-1,3cyclohexadiene-1-carboxylate nor 3,6-dihydroxy- 
2,4-cyclohexadiene-1-carboxylate - plausible substrates for 2,5-DHBA production as these compounds have not been commercially available. Out of all tested compounds, only 4-oxo-L-proline, cis-4-hydroxy-L-proline, and, albeit to a much lesser extent, (R)- $\beta$-hydroxybutyrate acted as substrates for BDH2 (Table 3). Importantly, trans4-hydroxy-L-proline, which has been thought to be the product of this reductase activity so far, was not oxidized to 4-oxo-L-proline in the reverse reaction, indicating a stereospecific interconversion of only cis-4-hydroxy-L-proline and 4-oxo-L-proline in the presence of the enzyme. Furthermore, a negligible specific activity towards (R)- $\beta$-hydroxybutyrate

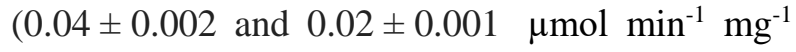
protein for $\mathrm{rBDH} 2$ and $\mathrm{hBDH} 2$, respectively) comparing with the results for cis-4-hydroxy$(15.73 \pm 0.37$ and $21.16 \pm 0.34$ for $\mathrm{rBDH} 2$ and hBDH2, respectively) and 4-oxo-L-proline (22.91 \pm 1.26 and $31.36 \pm 0.80$ for $\mathrm{rBDH} 2$ and $\mathrm{hBDH} 2$, respectively) indicate that (R)- $\beta$-hydroxybutyrate is unlikely to be a physiological substrate for BDH2.

It was previously reported that the optimum $\mathrm{pH}$ value for the reaction catalyzed by 4-oxo-Lproline reductase is about 6.5 (5). To verify this information, we determined the $\mathrm{pH}$ range of the reductase activity (Fig. 6). Interestingly, BDH2 remained catalytically active in a broad spectrum of the $\mathrm{pH}$ (from 5.5 through 9.0). Moreover, the $\mathrm{pH}$ optimum for the rat enzyme was more evident at 6.5 , while the human enzyme exhibited the highest activity in the $\mathrm{pH}$ range from 6.5 to 7.0 , with only a slight decrease in higher $\mathrm{pH}$ values. These results indicate that $\mathrm{BDH} 2$ is most likely the same enzyme as studied by Smith and Mitoma (5).

The kinetic properties of the recombinant $\mathrm{BDH} 2$ proteins were investigated in detail using homogenous recombinant proteins and are compared in Table 4. Both enzymes followed the Michaelis-Menten model of enzyme kinetics. Comparing with previous studies, $\mathrm{K}_{\mathrm{M}}$ values for 4oxo-L-proline obtained in our investigation $\left(\mathrm{K}_{\mathrm{M}} \approx\right.$ $0.4-0.5 \mathrm{mM}$ ) were comparable to those determined for the partially purified rabbit enzyme $\left(\mathrm{K}_{\mathrm{M}} \approx 0.6 \mathrm{mM}\right)$ (5). In contrast, an affinity for NADH seems to be much higher than shown by Smith and Mitoma $\left(\mathrm{K}_{\mathrm{M}} \approx 840 \mu \mathrm{M}\right)$ and was equal to about $2.845 \pm 0.76$ and $2.876 \pm 0.181 \mu \mathrm{M}$ for rat and human enzyme, respectively. These values are much more probable than the results reported previously, because of the observed saturation of the enzymes with $\mathrm{NADH}$ at a concentration of $50 \mu \mathrm{M}$.

\section{Evidence for cis-4-hydroxy-L-proline as the product of BDH2 activity}

So far, the reaction catalyzed by 4-oxo-L-proline reductase was only shown to produce 4-hydroxy-Lproline $(4,5)$, but the specific isomer of the product has never been described. To determine the stereochemistry of 4-hydroxy-L-proline generated by recombinant human $\mathrm{BDH} 2$, the deproteinized reaction mixture was subjected to precolumn chiral derivatization with $\mathrm{N \alpha}$-(5-fluoro-2,4dinitrophenyl)-1-valine amide (L-FDVA) followed by RP-HPLC and mass spectrometric analysis (8). As shown in Fig. 7, chromatographic analysis of the product revealed its perfect comigration with a commercial standard of cis-4-hydroxy-L-proline. The addition of cis-4-hydroxy-L-proline to the reaction mixture resulted in a selective increase in the peak area of the product (from 6,101 to 21,577 units) without a noticeable disturbance in its peak symmetry, confirming the product's identity as the cis isomer of 4-hydroxy-L-proline. Analysis of the product by electrospray mass spectrometry indicated the presence of a protonated molecular ion with $\mathrm{m} / \mathrm{z} 412$, as expected for the L-FDVA derivative of cis-4-hydroxy-L-proline, which was indeed identical with that of the commercial standard of this amino acid (Fig. 7). The recorded mass spectrum of cis-4-hydroxy-L-proline was also in agreement with previously reported results on the L-FDVA derivative of 4-hydroxy-L-proline (8). Similar results of RP-HPLC-MS analysis were obtained for rat recombinant BDH (not shown).

These results confirm that $\mathrm{BDH} 2$ catalyzes the formation only of cis-4-hydroxy-L-proline that has been considered an exogenous and nonphysiological metabolite in mammalians so far. 
HEK293T cells metabolize 4-oxo-L-proline into cis-4-hydroxy-L-proline

To verify whether 4-oxo-L-proline is converted into cis-4-hydroxy-L-proline in human cells, we investigated its metabolism in the intact HEK293T cells that express BDH2 enzyme (Fig. 9). The cells were incubated in the absence or presence of $1 \mathrm{mM}$ 4-oxo-L-proline for up to $72 \mathrm{~h}$. Next, samples of culture medium were withdrawn, deproteinized with perchloric acid, neutralized, and derivatized with L-FDVA. The concentrations of trans- and cis-4-hydroxy-L-proline were determined by RPHPLC-MS, whereas the consumption of 4-oxo-Lproline was followed spectrophotometrically.

As shown in Fig. 9, HEK293T constantly took up 4-oxo-L-proline from the culture medium and converted it into cis-4-hydroxy-L-proline that was then released back into the extracellular milieu. No formation of cis-4-hydroxy-L-proline was detected in the absence of 4-oxo-L-proline (not shown). After $72 \mathrm{~h}$ of incubation, the extracellular concentration of 4-oxo-L-proline dropped by $\approx 0.5 \mathrm{mM}$, whereas the cis-4-hydroxyL-proline accumulated up to $\approx 0.3 \mathrm{mM}$. More intriguingly, the formation of cis isomer was accompanied by an accumulation of the trans one at up to $\approx 0.2 \mathrm{mM}$ concentration. These results suggested that a considerable fraction of cis-4hydroxy-L-proline might have been converted into the trans isomer, a physiological metabolite in mammalians. Alternatively, 4-oxo-L-proline might have exerted an inhibitory action on the breakdown of the endogenous trans-4-hydroxy-L-proline. The substoichiometric production of cis-4hydroxy-L-proline would then reflect its retention in the intracellular spaces accompanied by its incorporation into cell proteins (9). To verify these hypotheses, we investigated the metabolic fate of the cis isomer in HEK293T. As shown in Fig. 9, the cells did neither convert cis-4-hydroxy-L-proline into trans-4-hydroxy-L-proline nor accumulate the latter metabolite in the culture medium, indicating both a lack of cis-trans isomerization of 4-hydroxyL-proline and any impact of the cis isomer on the metabolism of the endogenous trans-4-hydroxy-Lproline. These findings imply that 4-oxo-L-proline acts as an inhibitor of the trans-4-hydroxy-Lproline breakdown in HEK293T cells.

A routine daily inspection of HEK293T cultures indicated that the cells incubated in the presence of 4-oxo-L-proline might show a higher death rate than the control ones. To test this possibility, the viability of both control and 4-oxoL-proline-treated cells was determined using the MTT assay.

As shown in Fig. 10, prolonged incubation of the cells with the amino acid led to a decrease in their viability by $\approx 50 \%$ in comparison with that determined for the control cells, suggesting an antiproliferative and cytotoxic effect of cis-4hydroxy-L-proline as reported previously $(10,11)$. A similar impact on the cell viability was also found with African green monkey COS-7 cells (not shown).

Taken together, these results indicate that $\mathrm{BDH} 2$ enzyme is operational in the intact HEK293T cells, yielding cis-4-hydroxy-L-proline, a non-physiological and potentially toxic metabolite, whereas 4-oxo-L-proline is most likely an inhibitor of trans-4-hydroxy-L-proline metabolism in human cells.

\section{Discussion}

Although the reaction catalyzed by 4-oxo-L-proline reductase is currently considered a normal part of metabolic pathways for L-proline degradation in mammalians, as depicted in the Kyoto Encyclopedia of Genes and Genomes (KEGG) for example (12), the identity of this enzyme and its biological impotence are still unknown. Here, we report the identification of rat 4-oxo-L-proline reductase as $\mathrm{BDH} 2$, disclosing the identity of the mammalian enzyme. This conclusion is based on the following findings: (i) a multistep purification of the 4-oxo-L-proline-reducing activity from rat kidneys resulted in the identification of the protein $\mathrm{BDH} 2$ as the only meaningful candidate for the enzyme; (ii) the recombinant rat and human $\mathrm{BDH} 2$ catalyze the NADH-dependent reduction of 4-oxoL-proline, yielding cis-4-hydroxy-L-proline, whereas mutants of these enzymes harboring mutations of the key catalytic residues (Y157F and 
Y147F, respectively) are catalytically inactive; and (iii) the identity of the product made by the recombinant enzymes was confirmed by both reversed-phase chromatography and mass spectrometry. The identification of 4-oxo-L-proline reductase as $\mathrm{BDH} 2$ is also consistent with the findings that HEK293T cells endogenously expressing BDH2 protein efficaciously convert 4oxo-L-proline to cis-4-hydroxy-L-proline, whereas no other enzyme has been shown to generate the $c i s$ isomer of 4-hydroxy-L-proline in vertebrates yet (for review see Ref. 13).

$\mathrm{BDH} 2$ has a typical $\mathrm{NAD}(\mathrm{H})$ binding Rossmann-fold domain in its structure and belongs to the short-chain dehydrogenase/reductase (SDR) superfamily. In humans, enzymes of this cluster are involved in the metabolism of a large variety of compounds, including steroid hormones, lipids, and xenobiotics (14). BDH2 was initially reported as a putative cytosolic $\beta$-hydroxybutyrate dehydrogenase contributing to the oxidation of the ketone body $\beta$-hydroxybutyrate (6). But the enzyme was shown to be very poor in oxidizing $\beta$ hydroxybutyrate, with a $K_{M}$ of $12 \mathrm{mM}$ and $k_{\text {cat }}$ value of $1 \mathrm{~min}^{-1}$ at $50 \mathrm{mM}$ concentration of the substrate, which also finds confirmation in the present study. Such a low turnover number of the enzyme, resembling that for an enzyme of posttranslational modification rather than for a metabolic one (15), clearly pleads against $\beta$-hydroxybutyrate being its physiological substrate. Indeed, no disturbances in ketone bodies metabolism were found in $\mathrm{BDH} 2$ deficient mice (16). Alternatively, BDH2 was proposed to be the homolog of bacterial EntA protein, which reduces 2,3-dihydro-2,3dihydroxybenzoic acid (2,3-diDHBA) to 2,3dihydroxybenzoic acid (2,3-DHBA), and to catalyze the synthesis of 2,5-dihydroxybenzoic acid (2,5-DHBA, gentisic acid), a putative mammalian siderophore (7). Intriguingly, BDH2 has never been shown in a direct experiment (i.e. in vitro) to catalase the production of 2,5-DHBA and instead of this, the formation of 2,3-DHBA from 2,3-diDHBA in the presence of the enzyme was evidenced (7). It is also unclear which metabolic pathway could provide a putative substrate for the BDH2dependent formation of 2,5-DHBA in mammalians.
For these and other factual reasons, the physiological role of 2,5-DHBA and the importance of $\mathrm{BDH} 2$ for its synthesis were questioned experimentally by others (17).

We show in the present work that $\mathrm{BDH} 2$ catalyzes the reversible reduction of 4-oxo-Lproline to cis-4-hydroxy-L-proline, with a high substrate specificity and catalytic activity. The formation of cis-4-hydroxy-L-proline is remarkable as, to our knowledge, no enzyme has been shown to catalase the production of the cis isomer in vertebrate species to date. This finding also reveals that the irreversibility of this reaction reported by Smith and Mitoma (5) was only apparent, and resulted from the use of trans-4-hydroxy-L-proline in enzymatic tests. Concerning the plausible substrates, neither 5-oxo-L-proline nor trans-4hydroxy-L-proline was accepted, indicating a preferential requirement for the presence of an $\mathrm{OH} /$ keto group at carbon 4 position and specific spatial orientation of $4 \mathrm{OH}$ group in a reduced substrate. The catalytic efficiency $\left(\mathrm{k}_{\mathrm{cat}} / \mathrm{K}_{\mathrm{M}}\right)$ of the human enzyme on 4-oxo-L-proline $\left(2450 \mathrm{~min}^{-1} \times\right.$ $\mathrm{mM}^{-1}$ ) was 9400 -fold higher than that on (R)- $\beta$ hydroxybutyrate $\left(0.26 \mathrm{~min}^{-1} \times \mathrm{mM}^{-1}, 6\right)$, confirming that the latter compound is unlikely to be a physiological substrate. Whereas a very weak activity towards (R)- $\beta$-hydroxybutyrate and no activity on acetoacetate imply that cyclic compounds are much better substrates for $\mathrm{BDH} 2$ than the linear ones. Unfortunately, no information on the specific activity and the kinetic parameters of $\mathrm{BDH} 2$ for 2,3-diDHBA was reported by Devireddy and colleagues (7), hence it is impossible to compare the catalytic activity of the enzyme on 2,3-diDHBA to that determined for 4oxo-L-proline.

The results presented here identified 4-oxoL-proline as a novel substrate for BDH2. Although this amino acid is a poorly studied metabolite, it is occasionally detected in metabolomics experiments as a constituent of both human plasma $(3,18)$ and cells $(2,19)$. The origin of 4-oxo-L-proline is currently unclear, but the finding that its intracellular concentration doubled in human $\mathrm{T}$ cells incubated with a high concentration of Larginine suggests that 4-oxo-L-proline is indeed 
an endogenous metabolite, most likely contributing to L-arginine/L-proline metabolic pathways (19). Also, 4-oxo-L-proline might come from food as it is detected in dairy products for example (20). An alternative explanation would be that 4-oxo-Lproline is endogenously produced from cis-4hydroxy-L-proline in the reverse reaction catalyzed by $\mathrm{BDH} 2$. This enzyme is certainly capable to catalyze such a reaction in vitro in the presence of $\mathrm{NAD}^{+}$at a $1 \mathrm{mM}$ concentration that is well within the physiological values reported in human cells $(0.2-1 \mathrm{mM}, 21)$. But in contrast to this reflection, no conversion of cis-4-hydroxy-L-proline into 4oxo-L-proline was detected in HEK293T cells incubated with the former compound, suggesting that the reduction of 4-oxo-L-proline is the preferred reaction in vivo.

The incubation of HEK293T cells in the presence of 4-oxo-L-proline resulted not only in its conversion to cis-4-hydroxy-L-proline but also in a considerable accumulation of trans-4-hydroxy-Lproline in the culture medium; whereas no production of trans-4-hydroxy-L-proline was detected in cells incubated with cis-4-hydroxy-Lproline alone. This indicates that 4-oxo-L-proline is most likely an inhibitor of hydroxyproline dehydrogenase (Proline dehydrogenase 2, PRODH2) that converts trans-4-hydroxy-L-proline to delta-1-pyrroline-3-hydroxy-5-carboxylate, hence initiating the degradation of the endogenous trans-4-hydroxy-L-proline. Thus, 4-oxo-L-proline apparently blocks the degradation pathway of trans-4-hydroxy-L-proline in HEK293T cells, resulting in its accumulation in the culture medium. This effect in fact resembles the biochemical phenotype associated with the deficiency of hydroxyproline dehydrogenase, a benign metabolic disorder (22). Interestingly, several analogs of trans-4-hydroxy-L-proline were tested as potential inhibitors of PRODH2, including trans-4-hydroxyL-proline, cis-4-hydroxy-L-proline, and cis-4hydroxy-D-proline, but none of them caused inhibition at a concentration as high as $5 \mathrm{mM}$ (23). Further studies are thus needed to evaluate the effect of 4-oxo-L-proline and its analogues on PRODH2 activity as inhibitors of this enzyme could have therapeutic value in the primary hyperoxalurias (23).

In conclusion, we have shown here that mammalian BDH2 is 4-oxo-L-proline reductase, an enzyme catalyzing reversible reduction of 4-oxo-Lproline to cis-4-hydroxy-L-proline, and not to trans-4-hydroxy-L-proline as currently believed. $\mathrm{BDH} 2$ is therefore the first enzyme capable of producing the cis isomer of 4-hydroxy-L-proline to be identified in vertebrates. $\mathrm{BDH} 2$ also allows intact HEK293T cells to metabolize 4-oxo-Lproline to cis-4-hydroxy-L-proline which is now thought an exogenous metabolite in vertebrates. Finally, this work also shows that 4-oxo-L-proline may act as an inhibitor of the trans-4-hydroxy-Lproline breakdown in human cells.

\section{Experimental procedures}

\section{Materials}

Reagents, of analytical grade whenever possible, were from Sigma or Merck (Darmstadt, Germany). 4-oxo-L-proline hydrobromide was purchased from Alfa Aesar (90+\% purity, Ward Hill, USA) or Fluorochem (95\% purity, Hadfield, UK). QSepharose FF resin, HiScreen Blue FF, Superdex 200 16/60 HiLoad, and HisTrap FF crude columns were obtained from GE Healthcare Bio-Sciences (Uppsala, Sweden). Vivaspin 20 centrifugal concentrators were from Sartorius (Stockport, UK). Enzymes and DNA modifying enzymes were obtained from Thermo-Fermentas (Waltham, USA), A\&A Biotechnology (Gdynia, Poland), or Bio-Shop (Burlington, Canada).

\section{Assay of 4-oxo-L-proline reductase activity}

The enzyme activity was determined by the modified method employed previously (5). Briefly, the activity was followed spectrophotometrically at $37^{\circ} \mathrm{C}$ by measuring the rate of NADH conversion into $\mathrm{NAD}^{+}$, which is accompanied by a decrease in absorbance at $\lambda=340 \mathrm{~nm}\left(\varepsilon=6.22 \mathrm{mM}^{-1} \mathrm{~cm}^{-1}\right)$. The standard incubation mixture $(1 \mathrm{ml})$ contained $80 \mathrm{mM} \mathrm{Na}{ }^{+}$Phosphate, $\mathrm{pH}$ 6.5; 1 mM DTT; $0.2 \mathrm{mM}$ $\mathrm{NADH} ; 2 \mathrm{mM}$ 4-oxo-L-proline. The latter one was 
prepared as a fresh $25 \mathrm{mM}$ solution and $\mathrm{pH}$ adjusted to 6.0 with $1 \mathrm{M} \mathrm{NaHCO}_{3}$ and filtered using $0.22 \mu \mathrm{m}$ Spin-X cellulose acetate centrifuge tube filters (Costar, USA). The actual concentration of 4-oxoL-proline in the stock solution was verified spectrophotometrically. The reaction was started by the addition of the enzyme preparation and carried out at $37^{\circ} \mathrm{C}$ for $15 \mathrm{~min}$ unless otherwise described. Kinetic properties and substrate specificity of the $\mathrm{BDH} 2$ enzymes were determined in the standard incubation mixture supplemented with $0.1 \mathrm{mg} / \mathrm{ml}$ bovine serum albumin. Oxidase activity of both enzymes was determined in the analogical buffer with $50 \mathrm{mM}$ Tris- $\mathrm{HCl}, \mathrm{pH} 9.0$ in the presence of $1 \mathrm{mM} \mathrm{NAD}^{+}$instead of $0.2 \mathrm{mM} \mathrm{NADH}$. All reactions were linear for at least $10 \mathrm{~min}$ under all studied conditions.

\section{Purification of rat 4-oxo-L-proline reductase}

Eighteen male WAG rats, aged 3 months, were purchased from the Animal House of the Mossakowski Medical Research Centre, Polish Academy of Sciences (Warsaw, Poland). The animals were euthanized by a carbon dioxide euthanasia (Directive 2010/63/EU of the European Parliament). Rat kidneys (40 g) were homogenized in a Waring Blender 7011HS (4 cycles $\times 30 \mathrm{sec}$ with 10 -sec pause) with three volumes $(\mathrm{w} / \mathrm{v})$ of a buffer consisting of $20 \mathrm{mM}$ Tris- $\mathrm{HCl}, \mathrm{pH} 8.0$, $1 \mathrm{mM}$ DTT, $20 \mathrm{mM} \mathrm{KCl}, 4 \mu \mathrm{g} / \mathrm{ml}$ leupeptin. The homogenate was centrifuged for $20 \mathrm{~min}$ at $15,000 \times \mathrm{g}$ at $4^{\circ} \mathrm{C}$. The resulting supernatant $(120 \mathrm{ml})$ was then fractionated between $0 \%$ and $10 \%$ concentration (w/v) of polyethylene glycol 4000. After $15 \mathrm{~min}$ incubation on ice, the sample was centrifuged for $10 \mathrm{~min}$ at $15,000 \times \mathrm{g}$ at $4^{\circ} \mathrm{C}$. The supernatant was again submitted for fractionation with PEG-4000 concentration (w/v) between $10 \%$ and $25 \%$. After $15 \mathrm{~min}$ incubation on ice, the sample was centrifuged for $10 \mathrm{~min}$ at $15,000 \times \mathrm{g}$ at $4^{\circ} \mathrm{C}$. The $10-25 \%$ precipitate was dissolved in $120 \mathrm{ml}$ of homogenization buffer and frozen at $-70^{\circ} \mathrm{C}$ before purification.

Clarified sample $10-25 \%$ was applied to a Q Sepharose column $(100 \mathrm{ml})$ equilibrated with buffer A consisting of $20 \mathrm{mM}$ Tris- $\mathrm{HCl}, \mathrm{pH} 8.0$,
$1 \mathrm{mM}$ DTT, $20 \mathrm{mM} \mathrm{KCl}, 1 \mu \mathrm{g} / \mathrm{ml}$ leupeptin. The column was washed with $240 \mathrm{ml}$ of buffer A, developed with a linear $\mathrm{NaCl}$ gradient $(0-1 \mathrm{M}$ in $400 \mathrm{ml}$ ) in buffer $\mathrm{A}$, and fractions $(5 \mathrm{ml})$ were collected. The most active fractions from the Q Sepharose column were pooled $(20 \mathrm{ml})$, diluted to $54 \mathrm{ml}$ with buffer $\mathrm{C}\left(80 \mathrm{mM} \mathrm{Na}{ }^{+}\right.$Phosphate, $\mathrm{pH} 6.5, \quad 1 \mathrm{mM}$ DTT, $20 \mathrm{mM} \mathrm{KCl}, \quad 0.5 \mathrm{mM}$ phenylmethylsulfonyl fluoride (PMSF), and applied to a HiScreen Blue FF column $(4.7 \mathrm{ml})$ equilibrated with buffer $\mathrm{C}$. The column was washed with $56 \mathrm{ml}$ of buffer $\mathrm{C}$, developed with a linear $\mathrm{NaCl}$ gradient $(0-1.5 \mathrm{M}$ in $51 \mathrm{ml})$ in buffer $\mathrm{C}$, and fractions $(3 \mathrm{ml})$ were collected. The most active fractions from the HiScreen Blue FF column $(12 \mathrm{ml})$ were pooled, concentrated to $4.5 \mathrm{ml}$ using Vivaspin 20 ultrafiltration unit, and $2 \mathrm{ml}$ of the sample was loaded on a Superdex 200 16/60 HiLoad column $(120 \mathrm{ml})$ equilibrated with buffer D consisting of $80 \mathrm{mM} \mathrm{Na}{ }^{+}$Phosphate, $\mathrm{pH} 6.5,1 \mathrm{mM}$ DTT, $20 \mathrm{mM} \mathrm{KCl}, 0.1 \mathrm{M} \mathrm{NaCl}$. The gel filtration column was then developed with $140 \mathrm{ml}$ of buffer $\mathrm{C}$ and $2 \mathrm{ml}$ fractions were collected. All purification steps were performed at $4{ }^{\circ} \mathrm{C}$ and the enzymatic preparation was stored at $-70^{\circ} \mathrm{C}$ between steps.

\section{Identification of the rat 4-oxo-L-proline reductase by tandem mass spectrometry}

The protein bands of the most active fractions coeluting with 4-oxo-L-proline reductase activity in the Superdex 200 16/60 HiLoad purification step were cut from a $10 \%$ polyacrylamide SDS gel and digested with trypsin. Appropriate negative controls from two fractions lacking the activity were prepared as well. In-gel digestions of the peptides were performed as described previously (24). Peptides were analyzed by nanoUPLCtandem mass spectrometry employing Acquity nanoUPLC coupled with a Synapt G2 HDMS QTOF mass spectrometer (Waters, Milford, USA) fitted with a nanospray source and working in $\mathrm{MS}^{\wedge} \mathrm{E}$ mode under default parameters. Briefly, the products of in-gel protein digestion were loaded onto a Waters Symmetry C18 trapping column (20 $\mathrm{mm} \times 180 \mu \mathrm{m})$ coupled to the Waters BEH130 C18 UPLC column $(250 \mathrm{~mm} \times 75 \mu \mathrm{m})$. The peptides 
were eluted from these columns in a 1-85\% gradient of acetonitrile in water (both containing $0.1 \%$ formic acid) at a flow rate of $0.3 \mu \mathrm{l} / \mathrm{min}$. The peptides were directly eluted into the mass spectrometer. Data were acquired and analyzed using MassLynx 4.1 software (Waters, USA) and ProteinLynx Global Server 2.4 software (PLGS, Waters, USA) with a False Discovery Rate $\leq 4 \%$. To identify 4-oxo-L-proline reductase, the complete rat (Rattus norvegicus) reference proteome was downloaded from the NCBI Protein database, randomized, and used as a databank for the MS/MS software.

\section{Overexpression and purification of the recombinant $\mathrm{BDH} 2$ proteins and inactive mutants}

Rat total RNA was prepared from $100 \mathrm{mg}$ of kidneys with the use of TriPure reagent (Roche, Switzerland) according to the manufacturer's instructions. cDNA was synthesized using Moloney murine leukemia virus reverse transcriptase (TranScriba, A\&A Biotechnology, Poland), with oligo(dT) ${ }_{18}$ primer and $2.5 \mathrm{mg}$ total RNA according to the manufacturer's instructions. The open reading frame (ORF) encoding human enzyme was purchased from DNASU Plasmid Repository (cloneID: HsCD00640151). The open reading frames encoding rat (NCBI Reference Sequence: NM_001106473.1) and human (NM_020139.4) BDH2 protein were PCRamplified using Pfu DNA polymerase. Both rat and human ORFs coding for BDH2 were amplified using specific 5' primers containing the initiator codon included in the NdeI site and 3' primers containing the stop codon flanked by a KpnI site (for primer sequence refer to table 5).

The amplified DNA products of the expected size were digested with the appropriate restriction enzymes and cloned into the pCOLD I expression vector (Takara Bio, Kusatsu, Japan), which allows for the production of proteins with an $\mathrm{N}$-terminal $\mathrm{His}_{6}$ tag. All constructs were verified by DNA sequencing.

For protein production, E. coli BL21(DE3) cells were transformed with an appropriate DNA construct and a single colony was selected to start an over-night pre-culture. $300 \mathrm{~mL}$ of LB broth (with $100 \mathrm{mg} / \mathrm{mL}$ ampicillin) was inoculated with $30 \mathrm{ml}$ of the pre-culture and incubated at $37^{\circ} \mathrm{C}$ and $175 \mathrm{rpm}$ until an $\mathrm{OD}_{600}$ of 0.5 was reached. The culture was placed on ice for 20 min (cold-shock) to induce protein expression. Cells were incubated for $16 \mathrm{~h}$ at $13^{\circ} \mathrm{C}, 175 \mathrm{rpm}$, and harvested by centrifugation $(6000 \times \mathrm{g}$ for $10 \mathrm{~min})$. The cell paste was suspended in $15 \mathrm{ml}$ lysis buffer consisting of $80 \mathrm{mM} \mathrm{Na}{ }^{+}$Phosphate, $\mathrm{pH}$ 6.5, $1 \mathrm{mM}$ DTT, $20 \mathrm{mM}$ $\mathrm{KCl}, 1 \mathrm{mM}$ PMSF, $5 \mu \mathrm{g} / \mathrm{ml}$ leupeptin, $5 \mu \mathrm{g} / \mathrm{ml}$ antipain, $0.25 \mathrm{mg} / \mathrm{ml}$ hen egg-white lysozyme (BioShop, Canada) and $250 \mathrm{U}$ of Viscolase (A\&A Biotechnology, Poland). The cells were lysed by freezing in liquid nitrogen and, after thawing and vortexing, the extracts were centrifuged at $4{ }^{\circ} \mathrm{C}$ $(20,000 \times \mathrm{g}$ for $20 \mathrm{~min})$.

For the purification of recombinant $\mathrm{BDH} 2$ proteins, the supernatant of E. coli lysate $(15 \mathrm{ml})$ was diluted 3-fold with buffer A (100 mM Na ${ }^{+}$Hepes pH 8.0, $200 \mathrm{mM} \mathrm{NaCl}, 30 \mathrm{mM}$ imidazole, $1 \mu \mathrm{g} / \mathrm{ml}$ leupeptin, $1 \mu \mathrm{g} / \mathrm{ml}$ antipain) and applied onto a HisTrap FF crude column (1 ml) equilibrated with the same buffer. The column was then washed with $10 \mathrm{ml}$ buffer $\mathrm{A}$, and the retained proteins were eluted with a stepwise gradient of imidazole $(5 \mathrm{ml}$ of $90 \mathrm{mM}, 5 \mathrm{ml}$ of $180 \mathrm{mM}$, and 5 $\mathrm{ml}$ of $300 \mathrm{mM}$ ) in buffer A. The recombinant proteins were present in both $180 \mathrm{mM}$ and $300 \mathrm{mM}$ imidazole fractions. Both fractions exhibited $>95 \%$ purity as confirmed by SDS-PAGE. The enzyme preparation was submitted to dialysis against buffer consisted of $80 \mathrm{mM} \mathrm{Na}{ }^{+}$Phosphate, $\mathrm{pH} 7.5,1 \mathrm{mM}$ DTT, $100 \mathrm{mM} \mathrm{NaCl}, 6 \%$ sucrose, $1 \mu \mathrm{g} / \mathrm{ml}$ leupeptin, $1 \mu \mathrm{g} / \mathrm{ml}$ antipain. The purified proteins were aliquoted and stored at $-70^{\circ} \mathrm{C}$.

Mutated forms of rat and human $\mathrm{BDH} 2$ enzymes (Y157F and Y147F, respectively) were generated by site-directed mutagenesis using a QuikChange II XL kit (Stratagene, La Jolla, CA, USA), with pCOLD I/rBDH2 and pCOLD I/hBDH2 plasmids as templates and mutagenic primers Y157F-rBDH2-S and Y157FrBDH2-AS as well as Y147F-hBDH2-S and Y147F-hBDH2-AS, respectively (see table 5). Both mutated forms of $\mathrm{BDH} 2$ were then produced in $E$. 
coli BL21(DE3) and purified using HisTrap FF crude column ( $1 \mathrm{ml})$ as described for the wild type enzymes (data not shown).

\section{Product analysis}

\section{Products of enzymatic reaction}

To obtain products formed in the reactions catalyzed by recombinant $\mathrm{BDH} 2$ proteins for mass spectrometry analysis, $2 \mu \mathrm{g}$ of the homogenous recombinant enzyme was incubated in the reaction mixture $(1 \mathrm{ml})$ containing $10 \mathrm{mM} \mathrm{Na}{ }^{+}$Phosphate, pH 6.5; 1 mM DTT; 0.2 mM NADH, and $2 \mathrm{mM} 4-$ oxo-L-proline. The reaction was started by the addition of $\mathrm{BDH} 2$ and followed up spectrophotometrically as described above. After 0 and $15 \mathrm{~min}$ at $37^{\circ} \mathrm{C}, 0.9 \mathrm{ml}$ of the reaction mixture was removed and mixed with $200 \mu \mathrm{l}$ of ice-cold $10 \%(\mathrm{w} / \mathrm{v}) \mathrm{HClO}_{4}$ to stop the reaction. Samples were centrifuged at $13,000 \times \mathrm{g}$ for $10 \mathrm{~min}$ at $4^{\circ} \mathrm{C}$ and the supernatants $(1.1 \mathrm{ml})$ were immediately withdrawn and neutralized with $70 \mu \mathrm{l}$ of $3 \mathrm{M}$ $\mathrm{KOH} / 3 \mathrm{M} \mathrm{KHCO}_{3}$. The salt precipitate was removed by centrifugation $(13,000 \times \mathrm{g}$ for $10 \mathrm{~min})$. The clear supernatants were subjected to precolumn chiral derivatization of 4-hydroxy-L-proline isomers with $\mathrm{N \alpha}$-(5-fluoro-2,4-dinitrophenyl)-1valine amide (L-FDVA), whereas the separation of derivatized amino acids was accomplished by RPHPLC according to a slightly modified method described by Langrock and coworkers (8). Briefly, twenty-five microliters of neutralized supernatant were mixed with $10 \mu \mathrm{l}$ of $1 \mathrm{M} \mathrm{NaHCO}$, followed by $40 \mu 1$ of $35 \mathrm{mM}$ L-FDVA (dissolved in acetone). The mixture was incubated for $90 \mathrm{~min}$ at $40^{\circ} \mathrm{C}$, and the reaction was stopped by the addition of $10 \mu \mathrm{l}$ $1 \mathrm{M} \mathrm{HCl}$. Next, the mixture was diluted with $50 \mu \mathrm{l}$ acetonitrile and $115 \mu 1$ water, and the samples were stored at $-20^{\circ} \mathrm{C}$ before further analysis. The amino acid derivatives were separated in a gradient mode on the Zorbax SB-C18 column (ODS, $4.6 \times 250$ $\mathrm{mm}, 5-\mu \mathrm{m}$ particle size) using Waters HPLC 600 system equipped with Waters 2487 UV detector and Waters ZQ quadrupole mass spectrometer fitted with an electrospray source. Mobile phases consisted of solvent A, containing $0.1 \%$ formic acid in the water, and solvent $\mathrm{B}$, containing $0.1 \%$ formic acid in acetonitrile. The separation was performed in a linear gradient from 20 to $30 \%$ of solvent B for $30 \mathrm{~min}$ and subsequently, from 30 to $65 \%$ for 19 $\mathrm{min}$ at a flow rate of $1 \mathrm{ml} / \mathrm{min}$, followed by the column equilibration for a further 11 min under the initial conditions. The column eluate was monitored by the UV detector at $\lambda=340 \mathrm{~nm}$, followed by the mass spectrometer, operating in positive electrospray ionization-MS mode. The mass spectral data were recorded for $\mathrm{m} / z=200-500$ to detect L-FDVA and derivatives of L-proline and 4-hydroxy-prolines. The ESI-MS source was set at a temperature of $90^{\circ} \mathrm{C}$, the capillary voltage of $3.0 \mathrm{kV}$, and cone voltage of $40 \mathrm{~V}$. The flow rate of the desolvation gas (nitrogen) was 900 liters/h. Quantification was achieved using external standards of all studied amino acids, after their derivatization with L-FDVA.

The above-described method did not allow us to obtain an L-FDVA-derivatized 4-oxo-Lproline. This is plausibly due to the chemical instability of 4-oxo-L-proline in the alkaline condition required for the reaction of derivatization (5).

\section{Products of 4-oxo-L-proline metabolism in mammalian cell cultures}

For the verification of BDH2 expression, lysates of African green monkey COS-7 cells (Cell Lines Service, Eppelheim, Germany) and human HEK293T cells (ECACC via Sigma-Aldrich, Poznan, Poland) were analyzed by western blotting, employing a polyclonal rabbit antibody against BDH2 (PA5-44760, Invitrogen, USA) and a horseradish peroxidase-conjugated goat anti-rabbit IgG antibody (AS09 602, Agrisera), as described previously (25).

To obtain products of 4-oxo-L-proline or cis-4-hydroxy-L-proline metabolism in intact COS7 and HEK293T cells for mass spectrometry analysis, COS-7 or HEK293T cells were plated in 6-well dishes $\left(9.5 \mathrm{~cm}^{2}\right)$ at a cell density of $0.35 \times 10^{6}$ or $0.60 \times 10^{6}$ cells/well, respectively, in Dulbecco's minimal essential medium (DMEM) supplemented with 100 units/ml penicillin, $100 \mathrm{~g} / \mathrm{ml}$ streptomycin, and $10 \%$ (v/v) fetal bovine 
serum and grown in a humidified incubator under a $95 \%$ air and $5 \% \mathrm{CO}_{2}$ atmosphere at $37^{\circ} \mathrm{C}$.

Twenty-four hours after seeding the cells, the culture medium was changed to a fresh one ( $2 \mathrm{ml}$ ) and supplemented with PBS (control), $1 \mathrm{mM}$ 4-oxo-L-proline, or $0.3 \mathrm{mM}$ cis-4-hydroxy-Lproline. Next, the cells were incubated for $0,24,48$ or $72 \mathrm{~h}$ before transferring the medium $(1 \mathrm{ml})$ to $100 \mu \mathrm{l}$ of $35 \%$ (w/v) $\mathrm{HClO}_{4}$. Precipitated protein was separated by centrifugation $(13,000 \times \mathrm{g}$ for 10 $\mathrm{min})$. After neutralization of the supernatant with 3 $\mathrm{M} \mathrm{KOH} / 3 \mathrm{M} \mathrm{KHCO}_{3}$, the salts were removed by centrifugation $(13,000 \times \mathrm{g}$ for $10 \mathrm{~min})$; the clear supernatant was subjected for derivatization with LFDVA to determine the products of 4-oxo-Lproline and cis-4-hydroxy-L-proline metabolism as described above, whereas the consumption of 4oxo-L-proline was measured spectrophotometrically with the use of recombinant BDH2.

\section{MTT cell viability assay}

COS-7 or HEK293T cells were seeded in 12-well dishes $\left(3.8 \mathrm{~cm}^{2}\right)$ at a cell density of $60 \times 10^{3}$ in $1 \mathrm{ml}$ DMEM supplemented with 100 units $/ \mathrm{ml}$ penicillin, $100 \mathrm{~g} / \mathrm{ml}$ streptomycin, and $10 \%$ (v/v) fetal bovine serum and grown in a humidified incubator under a $95 \%$ air and $5 \% \mathrm{CO}_{2}$ atmosphere at $37^{\circ} \mathrm{C}$.

Twenty-four hours after seeding the cells, the culture medium was changed to a fresh one ( $1 \mathrm{ml})$ and supplemented with either PBS (control) or $1 \mathrm{mM}$ 4-oxo-L-proline in PBS, and cultured further for $0,24,48$ or $72 \mathrm{~h}$. To determine the cell viability, $100 \mu \mathrm{l}$ of MTT $(5 \mathrm{mg} / \mathrm{ml}$ in PBS) was added to each well and the cells were incubated for an additional $30 \mathrm{~min}$ in the $\mathrm{CO}_{2}$ incubator. After the removal of the culture medium, the intracellular crystals of MTT-formazan were completely solubilized in $1 \mathrm{ml}$ of isopropanol:0.1 M HCl $(90: 10, \mathrm{v} / \mathrm{v})$. The resulting purple solution was centrifuged $(13,000 \times \mathrm{g}$ for $10 \mathrm{~min})$ to remove cell debris, and its absorbance was measured spectrophotometrically at $\lambda=570 \mathrm{~nm}$ (formazan) and $690 \mathrm{~nm}$ (reference) (26).

\section{Analytical methods}

Protein concentration was determined spectrophotometrically according to Bradford (27) using bovine $\gamma$-globulin as a standard. When appropriate, the His ${ }_{6}$-tagged recombinant proteins were detected by western blot analysis, employing a mouse primary monoclonal antibody against His $_{6-}$ tag (MA1-4806, Invitrogen, USA) and a horseradish peroxidase-conjugated goat antimouse antibody (A2554, Sigma-Aldrich, USA), as described previously (25). All western-blotting analyses employed chemiluminescence and signals acquisition with Amersham Hyperfilm ECL, with the pattern of the prestained protein ladder being copied from the blotting membrane onto the film using a set of felt-tip pens.

\section{Calculations}

$\mathrm{V}_{\max }, \mathrm{K}_{\mathrm{M}}$, and $\mathrm{k}_{\mathrm{cat}}$ for reductase activities of the studied enzymes were calculated with Origin 2020 software (OriginLab, USA) using nonlinear regression. All data are presented as mean \pm S.E.

Data availability: All data are contained within the article. 


\section{Funding and additional information}

This work was supported by DSM 501-D114-86-0117600-20 and DSM 501-D114-01-1140100 from the Polish Ministry of Science and High Education and partially by Opus-14 grant from the National Science Centre, Poland (2017/27/B/NZ1/00161). It was carried out with the use of the CePT infrastructure financed by the European Union European Regional Development Fund within the Operational Program "Innovative Economy” for 2007-2013.

\section{Conflict of Interest}

The authors declare no conflicts of interest in regards to this manuscript.

\section{References}

1. Semsary, S., Crnovčić, I., Driller, R., Vater, J., Loll, B., and Keller, U. (2018) Ketonization of Proline Residues in the Peptide Chains of Actinomycins by a 4-Oxoproline Synthase. Chembiochem: a European journal of chemical biology 19, 706-715

2. Figueroa M.E., Abdel-Wahab O., Lu C., Ward P.S., Patel J., Shih A., Li Y., Bhagwat N., Vasanthakumar A., Fernandez H.F., Tallman M.S., Sun Z., Wolniak K., Peeters J.K., Liu W., Choe S.E., Fantin V.R., Paietta E., Löwenberg B., Licht J.D., Godley L.A., Delwel R., Valk P.J., Thompson C.B., Levine R.L., Melnick A. (2010) Leukemic IDH1 and IDH2 mutations result in a hypermethylation phenotype, disrupt TET2 function, and impair hematopoietic differentiation. Cancer cell 18, 553-567

3. den Ouden H., Pellis L., Rutten G.E.H.M., Geerars-van Vonderen I.K., Rubingh C.M., van Ommen B., van Erk M.J., Beulens J.W.J. (2016) Metabolomic biomarkers for personalised glucose lowering drugs treatment in type 2 diabetes. Metabolomics 12, 27

4. Mitoma C., Smith T.E., Dacosta F.M., Udenfriend S., Patchett A.A., Witkop B. (1959) Studies on 4-keto-L-proline. Science 129, 95-96

5. Smith T.E., Mitoma C. (1962) Partial Purification and Some Properties of 4-Ketoproline Reductase. The Journal of Biological Chemistry 237, 1177-1180

6. Guo K., Lukacik P., Papagrigoriou E., Meier M., Lee H.W., Adamski J., Oppermann U. 2006. Characterization of Human DHRS6, an Orphan Short Chain Dehydrogenase/Reductase Enzyme. A novel, cytosolic type 2 R- $\beta$-hydroxybutyrate dehydrogenase. The Journal of Biological Chemistry 281: 10291-10297

7. Devireddy, L. R., Hart, D. O., Goetz, D. H., and Green, M. R. (2010) A mammalian siderophore synthesized by an enzyme with a bacterial homolog involved in enterobactin production. Cell 141, 1006-1017

8. Langrock, T., García-Villar, N., and Hoffmann, R. (2007) Analysis of hydroxyproline isomers and hydroxylysine by reversed-phase HPLC and mass spectrometry. Journal of Chromatography. B, Analytical technologies in the biomedical and life sciences 847, 282-288

9. Rosenbloom, J., and Prockop, D. J. (1971) Incorporation of cis-hydroxyproline into protocollagen and collagen. Collagen containing cis-hydroxyproline in place of proline and trans-hydroxyproline is not extruded at a normal rate. The Journal of Biological Chemistry 246, 1549-1555

10. Sturm, D., Maletzki, C., Braun, D., and Emmrich, J. (2010) cis-Hydroxyproline-mediated pancreatic carcinoma growth inhibition in mice. International Journal of Colorectal Disease 25, 921-929

11. Yoo, J. S., Sakamoto, T., Spee, C., Kimura, H., Harris, M. S., Hinton, D. R., Kay, E. P., and Ryan, S. J. (1997) cis-Hydroxyproline inhibits proliferation, collagen synthesis, attachment, and migration of cultured bovine retinal pigment epithelial cells. Investigative Ophthalmology \& Visual Science 38, 520-528 
bioRxiv preprint doi: https://doi.org/10.1101/2021.02.23.432487; this version posted February 23, 2021. The copyright holder for this preprint (which was not certified by peer review) is the author/funder, who has granted bioRxiv a license to display the preprint in perpetuity. It is made available under aCC-BY-NC-ND 4.0 International license.

12. Kanehisa, M., Furumichi, M., Tanabe, M., Sato, Y., and Morishima, K. (2017) KEGG: new perspectives on genomes, pathways, diseases and drugs. Nucleic Acids Research 45, D353D361

13. Bach, T. M., and Takagi, H. (2013) Properties, metabolisms, and applications of (L)-proline analogues. Applied Microbiology and Biotechnology 97, 6623-6634

14. Persson, B., Kallberg, Y., Bray, J. E., Bruford, E., Dellaporta, S. L., Favia, A. D., Duarte, R. G., Jörnvall, H., Kavanagh, K. L., Kedishvili, N., Kisiela, M., Maser, E., Mindnich, R., Orchard, S., Penning, T. M., Thornton, J. M., Adamski, J., and Oppermann, U. (2009) The SDR (shortchain dehydrogenase/reductase and related enzymes) nomenclature initiative. ChemicoBiological Interactions 178, 94-98

15. Kwiatkowski, S., Seliga, A. K., Vertommen, D., Terreri, M., Ishikawa, T., Grabowska, I., Tiebe, M., Teleman, A. A., Jagielski, A. K., Veiga-da-Cunha, M., and Drozak, J. (2018) SETD3 protein is the actin-specific histidine N-methyltransferase. eLife 7, e37921

16. Liu, Z., Ciocea, A., and Devireddy, L. (2014) Endogenous siderophore 2,5-dihydroxybenzoic acid deficiency promotes anemia and splenic iron overload in mice. Molecular and Cellular Biology 34, 2533-2546

17. Correnti, C., Richardson, V., Sia, A. K., Bandaranayake, A. D., Ruiz, M., Suryo Rahmanto, Y., Kovačević, Ž., Clifton, M. C., Holmes, M. A., Kaiser, B. K., Barasch, J., Raymond, K. N., Richardson, D. R., and Strong, R. K. (2012) Siderocalin/Lcn2/NGAL/24p3 does not drive apoptosis through gentisic acid mediated iron withdrawal in hematopoietic cell lines. PloS One 7, e43696

18. Walejko, J. M., Kim, S., Goel, R., Handberg, E. M., Richards, E. M., Pepine, C. J., and Raizada, M. K. (2018) Gut microbiota and serum metabolite differences in African Americans and White Americans with high blood pressure. International Journal of Cardiology 271, 336-339

19. Geiger, R., Rieckmann, J. C., Wolf, T., Basso, C., Feng, Y., Fuhrer, T., Kogadeeva, M., Picotti, P., Meissner, F., Mann, M., Zamboni, N., Sallusto, F., and Lanzavecchia, A. (2016). L-Arginine Modulates T Cell Metabolism and Enhances Survival and Anti-tumor Activity. Cell 167, 829842

20. Pan, L., Yu, J., Mi, Z., Mo, L., Jin, H., Yao, C., Ren, D., and Menghe, B. (2018) A Metabolomics Approach Uncovers Differences between Traditional and Commercial Dairy Products in Buryatia (Russian Federation). Molecules (Basel, Switzerland) 23, 735

21. Cantó, C., Menzies, K. J., and Auwerx, J. (2015) NAD(+) Metabolism and the Control of Energy Homeostasis: A Balancing Act between Mitochondria and the Nucleus. Cell Metabolism 22, 31-53

22. Mitsubuchi, H., Nakamura, K., Matsumoto, S., and Endo, F. (2008). Inborn errors of proline metabolism. The Journal of Nutrition 138, 2016S-2020S

23. Summitt, C. B., Johnson, L. C., Jönsson, T. J., Parsonage, D., Holmes, R. P., and Lowther, W. T. (2015) Proline dehydrogenase 2 (PRODH2) is a hydroxyproline dehydrogenase (HYPDH) and molecular target for treating primary hyperoxaluria. The Biochemical Journal 466, 273281

24. Shevchenko A., Tomas H., Havlis J., Olsen J.V., Mann M. (2006) In-gel digestion for mass spectrometric characterization of proteins and proteomes. Nature Protocols 1: 2856-2860

25. Drozak, J., Chrobok, L., Poleszak, O., Jagielski, A. K., and Derlacz, R. (2013) Molecular identification of carnosine $\mathrm{N}$-methyltransferase as chicken histamine N-methyltransferase-like protein (hnmt-like). PloS One 8, e64805

26. Mosmann T. (1983) Rapid colorimetric assay for cellular growth and survival: application to proliferation and cytotoxicity assays. Journal of Immunological Methods 65, 55-63

27. Bradford M.M. (1976) A Rapid and Sensitive Method for the Quantitation of Microgram Quantities of Protein Utilizing the Principle of Protein-Dye Binding. Analytical Biochemistry 72, 248-254 
Table 1. Purification of 4-oxo-L-proline reductase from rat kidneys.

\begin{tabular}{|c|c|c|c|c|c|c|}
\hline Fraction & $\begin{array}{l}\text { Volume } \\
\mathrm{ml}\end{array}$ & $\begin{array}{l}\text { Total protein } \\
m g\end{array}$ & 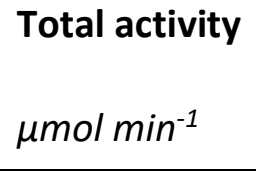 & $\begin{array}{l}\text { Specific activity } \\
\mu m o l \text { min }^{-1} \mathrm{mg}^{-1}\end{array}$ & $\begin{array}{l}\text { Purification } \\
\text {-fold }\end{array}$ & $\begin{array}{l}\text { Yield } \\
\%\end{array}$ \\
\hline $10 \%-20 \%$ PEG & 120 & 2343.75 & 13.666 & 0.006 & 1 & 100 \\
\hline Q Sepharose FF & 20 & 148.264 & 7.058 & 0.048 & 8 & 52 \\
\hline HiScreen Blue FF & 12 & 16.734 & 3.055 & 0.183 & 31 & 22 \\
\hline Superdex 200 16/60 HiLoad & 4.5 & 2.097 & 3.461 & 1.647 & 282 & 25 \\
\hline
\end{tabular}


Table 2. Proteins identified in fraction 28 from Superdex 200 purification step and gel bands submitted to trypsin digestion and MS/MS analysis.

Identified proteins are listed according to their score as calculated using ProteinLynx Global Server software (PLGS). For each protein, the molecular weight $(\mathrm{mW})$ and sequence coverage are also indicated. Occasional peptide hits corresponding to keratins have not been included.

\begin{tabular}{|c|c|c|c|c|c|}
\hline Source of protein & Protein name & $\begin{array}{l}\text { NCBI Protein } \\
\text { accession number }\end{array}$ & PLGS score* & MW (Da) & Coverage (\%) \\
\hline \multirow[t]{15}{*}{$\begin{array}{l}\text { Gel filtration fraction } \\
\text { (F28) }\end{array}$} & $60 \mathrm{kDa}$ heat shock protein mitochondrial & NP_071565.2 & 65806.8 & 60917 & 79.9302 \\
\hline & L lactate dehydrogenase B chain isoform Ldhbx & NP_001303262.1 & 20895.16 & 37307 & 50.1466 \\
\hline & ornithine aminotransferase mitochondrial precursor & NP_071966.1 & 20352.5 & 48302 & 64.2369 \\
\hline & isocitrate dehydrogenase NADP cytoplasmic & NP_113698.1 & 18164.1 & 46704 & 61.5942 \\
\hline & serine hydroxymethyltransferase mitochondrial & NP_001008323.1 & 8294.883 & 55729 & 55.754 \\
\hline & 3 hydroxybutyrate dehydrogenase type 2 & NP_001099943.1 & 6976.777 & 27660 & 33.3333 \\
\hline & protein disulfide isomerase $A 3$ precursor & NP_059015.1 & 6085.691 & 56553 & 26.7327 \\
\hline & hemoglobin alpha 2 & NP_001007723.1 & 5305.576 & 15274 & 43.662 \\
\hline & dihydrolipoyl dehydrogenase mitochondrial precursor & NP_955417.1 & 5272.024 & 54004 & 25.5403 \\
\hline & ezrin & NP_062230.1 & 5127.569 & 69347 & 23.7201 \\
\hline & adenylosuccinate synthetase isozyme 2 & NP_001099445.1 & 4400.901 & 50053 & 33.3333 \\
\hline & heat shock cognate $71 \mathrm{kDa}$ protein & NP_077327.1 & 3545.831 & 70827 & 22.6006 \\
\hline & kynurenine alpha aminoadipate aminotransferase mitochondrial & NP_058889.1 & 3483.156 & 47753 & 13.8824 \\
\hline & $\begin{array}{l}\text { enoyl CoA hydratase domain containing protein } 3 \text { mitochondrial } \\
\text { precursor }\end{array}$ & NP_001094480.1 & 2880.506 & 32364 & 16.6667 \\
\hline & cytosol aminopeptidase & NP_001011910.1 & 2736.271 & 56114 & 32.948 \\
\hline
\end{tabular}




\begin{tabular}{|c|c|c|c|c|c|}
\hline \multirow[t]{2}{*}{ Gel band $A$} & dimethylglycine dehydrogenase mitochondrial precursor & NP_620802.2 & 10426.36 & 95917 & 57.2929 \\
\hline & ezrin & NP_062230.1 & 1279.704 & 69347 & 19.6246 \\
\hline \multirow[t]{4}{*}{ Gel band B } & heat shock cognate $71 \mathrm{kDa}$ protein & NP_077327.1 & 17564.84 & 70827 & 60.6811 \\
\hline & GMP synthase glutamine hydrolyzing & NP_001019925.1 & 2311.621 & 76708 & 47.1861 \\
\hline & plastin 3 & NP_112346.1 & 1910.532 & 70704 & 38.254 \\
\hline & heat shock protein $75 \mathrm{kDa}$ mitochondrial precursor & NP_001034090.1 & 862.6176 & 80410 & 23.2295 \\
\hline \multirow[t]{2}{*}{ Gel band C } & 3 hydroxybutyrate dehydrogenase type 2 & NP_001099943.1 & 16517.04 & 27660 & 53.7255 \\
\hline & ornithine aminotransferase mitochondrial precursor & NP_071966.1 & 654.3914 & 48302 & 16.8565 \\
\hline
\end{tabular}

*PLGS score is calculated by the Protein Lynx Global Server (version 2.4) software using a Monte Carlo algorithm to analyze all acquired mass spectral data and is a statistical measure of the accuracy of assignation. A higher score implies greater confidence in protein identity. 
Table 3. Substrate specificity of the recombinant rat and human BDH2.

Activity assays were performed with the use of $2 \mu \mathrm{g}$ of recombinant BDH2 proteins in the presence of $0.2 \mathrm{mM}$ NADH or $1 \mathrm{mM} \mathrm{NAD}^{+}$when necessary, and $2 \mathrm{mM}$ concentration of the indicated substrate, with the exemption of (R)- $\beta$-hydroxybutyrate that was also tested at $50 \mathrm{mM}$ concentration. Values are the means \pm S.E. (error bars) of three independent experiments.

\begin{tabular}{lll} 
Substrate & hBDH2 & rBDH2 \\
\hline & $\mu m o l \mathrm{~min}^{-1} \mathrm{mg}^{-1}$ & $\mu \mathrm{mol} \mathrm{min}^{-1} \mathrm{mg}^{-1}$ \\
4-oxo-L-proline & $31.36 \pm 0.80$ & $22.91 \pm 1.26$ \\
5-oxo-L-proline & N.D. & N.D. \\
acetoacetate & N.D. & N.D. \\
trans-4-OH-L-proline & N.D. & N.D. \\
cis-4-OH-L-proline & $21.16 \pm 0.34$ & $15.73 \pm 0.37$ \\
(R)- $\beta$-hydroxybutyrate & N.D. & N.D. \\
(R)- $\beta$-hydroxybutyrate (50mM)* & $0.050 \pm 0.003$ & $0.040 \pm 0.002$ \\
\hline
\end{tabular}

* $50 \mathrm{mM}(\mathrm{R})-\beta$-hydroxybutyrate was employed previously (6) as a saturating concentration of the substrate

N.D. - not detectable 
Table 4. Kinetic properties of rat and human BDH2 proteins.

Kinetic properties were determined with the use of purified recombinant $N$-terminal His 6 tagged BDH2 proteins. Determinations for 4-oxo-L-proline were performed with $2 \mu \mathrm{g}$ of the enzyme preparations in the presence of $0.2 \mathrm{mM} \mathrm{NADH}$ and variable concentrations of 4-oxo-L-proline. The measurements for $\mathrm{NADH}$ were performed with $0.15 \mu \mathrm{g}$ of the enzyme preparations in the presence of $2 \mathrm{mM} 4$-oxo-L-proline and variable concentrations of NADH. Values are the means \pm S.E. (error bars) of three independent experiments.

$\begin{array}{lll}\text { Substrate } \quad \mathrm{rBDH} 2 & \mathrm{hBDH} 2\end{array}$

\begin{tabular}{lllllll} 
& $\mathrm{V}_{\max }$ & $\mathrm{K}_{\mathrm{M}}$ & $\mathrm{k}_{\mathrm{cat}}{ }^{*}$ & $\mathrm{~V}_{\max }$ & $\mathrm{K}_{\mathrm{M}}$ & $\mathrm{k}_{\mathrm{cat}}{ }^{*}$ \\
\hline & $\mu \mathrm{mol} \mathrm{min}^{-1} \mathrm{mg}^{-1}$ & $\mu M$ & $\mathrm{~s}^{-1}$ & $\mu m o l \mathrm{~min}^{-1} \mathrm{mg}^{-1}$ & $\mu M$ & $s^{-1}$ \\
4-oxo-L-proline & $28.29 \pm 0.42$ & $387.49 \pm 7.03$ & $14 \pm 0.21$ & $41.21 \pm 0.89$ & $483.03 \pm 0.01$ & $19.73 \pm 0.43$ \\
NADH & $20.50 \pm 0.70$ & $2.84 \pm 0.76$ & $10.15 \pm 0.35$ & $31.02 \pm 0.52$ & $2.88 \pm 0.18$ & $14.85 \pm 0.25$ \\
\hline
\end{tabular}

* calculated for the His 6 tagged recombinant enzymes with MW = 29703.14 and 28722.01 Da for rat and human enzyme, respectively 
Table 5. Sequences of primers used for PCR amplification of BDH2 ORFs and site-directed mutagenesis experiments.

The nucleotides corresponding to the coding sequences are in capital letters, restriction sites are underlined, and mutated codons are shown in boldface type.

$\begin{array}{ll}\text { Primer Sequence } & \begin{array}{l}\text { Restriction } \\ \text { site }\end{array}\end{array}$

\section{Wild-type BDH2 proteins}

\begin{tabular}{|c|c|c|c|}
\hline $\begin{array}{l}\text { rBDH2-pCOLD-S } \\
\text { rBDH2-pCOLD-AS }\end{array}$ & $\begin{array}{l}\text { tatacatATGTTTTTGGATTGCACTGCAGG } \\
\text { tataggtaccTCACAGACTCCAACCGCCATC }\end{array}$ & $\begin{array}{l}\text { Ndel } \\
\text { Kpnl }\end{array}$ & $\mathrm{N}$-terminal $\mathrm{His}_{6}$ tagged rat $\mathrm{BDH} 2$ \\
\hline $\begin{array}{l}\text { hBDH2-pCOLD-S } \\
\text { hBDH2-pCOLD-AS }\end{array}$ & $\begin{array}{l}\text { taatcatATGGGTCGACTTGATGGGAAAG } \\
\text { taaggtaccTCACAAGCTCCAGCCTCCATC }\end{array}$ & $\begin{array}{l}\text { Ndel } \\
\text { Kpnl }\end{array}$ & $\mathrm{N}$-terminal His6 tagged human $\mathrm{BDH} 2$ \\
\hline \multicolumn{4}{|c|}{$\begin{array}{l}\text { Site-directed mutagenesis } \\
\text { of BDH2 proteins }\end{array}$} \\
\hline $\begin{array}{l}\text { Y157F-rBDH2-S } \\
\text { Y157F-rBDH2-AS }\end{array}$ & $\begin{array}{l}\text { GAGAACAGATGTGTGTTCAGTGCAACCAAGG } \\
\text { CCTTGGTTGCACTGAACACACATCTGTTCTC }\end{array}$ & $\begin{array}{l}\text { N/A } \\
\text { N/A }\end{array}$ & $\begin{array}{l}N \text {-terminal } \mathrm{His}_{6} \text { tagged mutated form } \\
\text { of rat } \mathrm{BDH} 2\end{array}$ \\
\hline Y147F-hBDH2-AS & CAGATGTGTGTTCAGCACAACCAAGGCAGC & N/A & $\begin{array}{l}N \text {-terminal } \mathrm{His}_{6} \text { tagged mutated form } \\
\text { of human } \mathrm{BDH} 2\end{array}$ \\
\hline
\end{tabular}

N/A - not applicable 


\section{Figures}

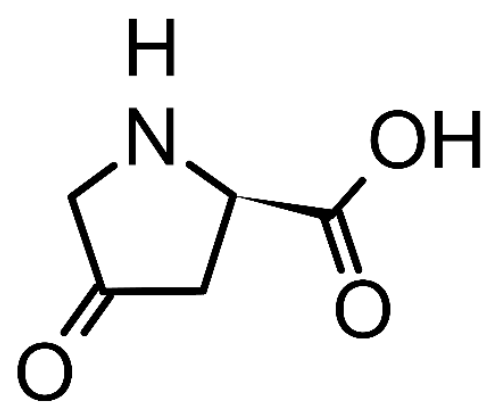

4-oxo-L-proline

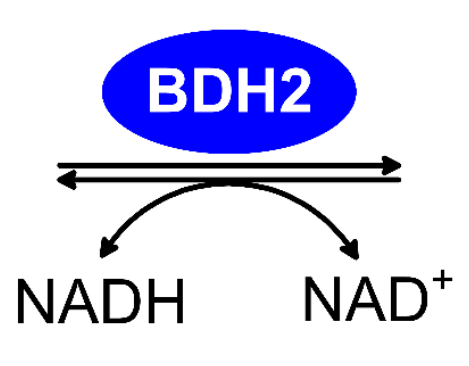

cis-4-OH-L-proline

Figure 1. Scheme of the reaction catalyzed by BDH2 as a 4-oxo-L-proline reductase. BDH2 also acts as a cis-4-OH-L-proline dehydrogenase in the presence of the $\mathrm{NAD}^{+}$in vitro. The biological relevance of the reverse reaction remains to be explored. 
Gallus gallus Homo sapiens Oryctolagus cuniculus Rattus norvegicus

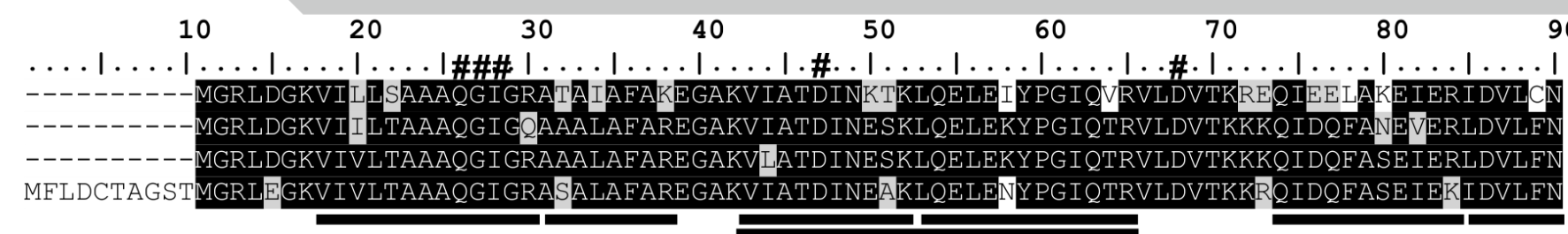

Identity $81 \%$ $90 \%$

$92 \%$ $100 \%$
Gallus gallus Homo sapiens Oryctolagus cuniculus Rattus norvegicus

Gallus gallus Homo sapiens

Oryctolagus cuniculus Rattus norvegicus classical short chain dehydrogenase/reductase 100

110120

130

140

150

160

170
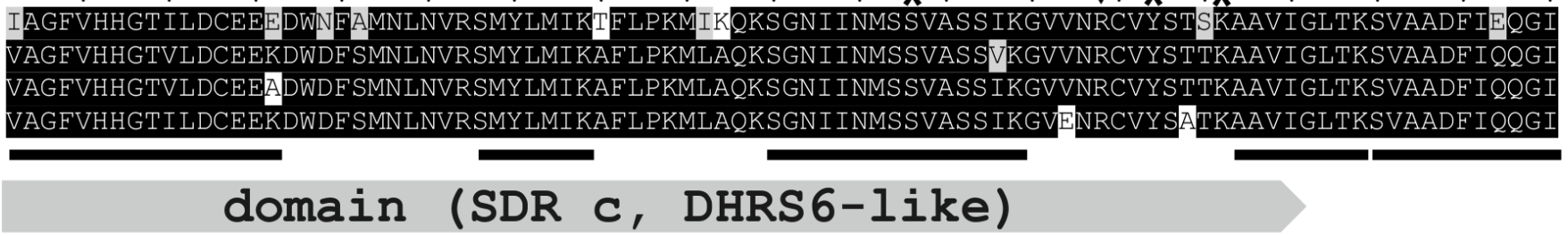

domain

(SDR

c, DHRS6-like)

190

200
$.1 \ldots$

210

220

230

240

250

\section{1

R

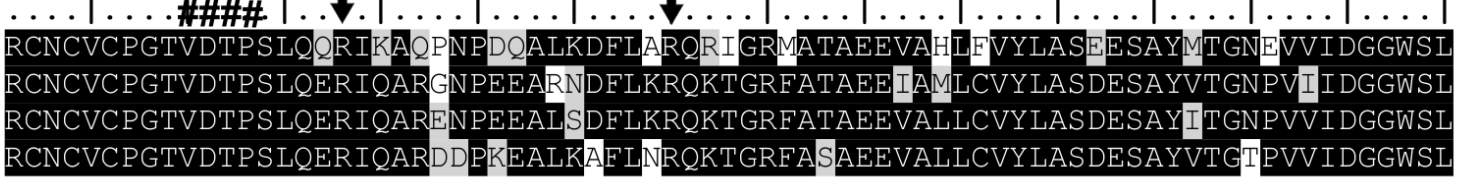

Figure 2. Amino acid sequence alignment of rat BDH2 protein with its orthologues. Sequences of rat (Rattus norvegicus, NP_001099943.1), human (Homo sapiens, NP_064524.3), rabbit (Oryctolagus cuniculus, XP_002717250.1), and chicken (Gallus gallus, XP_015141101.1) protein were obtained from the NCBI Protein database. Percentage of amino acid identities with rat BDH2 protein is given in the upper right. The characteristic one-domain architecture of the enzyme is indicated by the label above the alignment. Amino acid residues interacting with $\mathrm{NAD}(\mathrm{H})$ are indicated by hashes, whereas arginine residues coordinating the carboxylic group of a substrate are shown by arrows. Asterisks mark the key catalytic residues (6). The peptides identified by mass spectrometry in the protein purified from rat kidneys are underlined in the rat sequence, and several peptides covering similar though shorter sequences have been omitted. The level of residues conservation is indicated by black (100\%) and gray (50\% and more) background. 

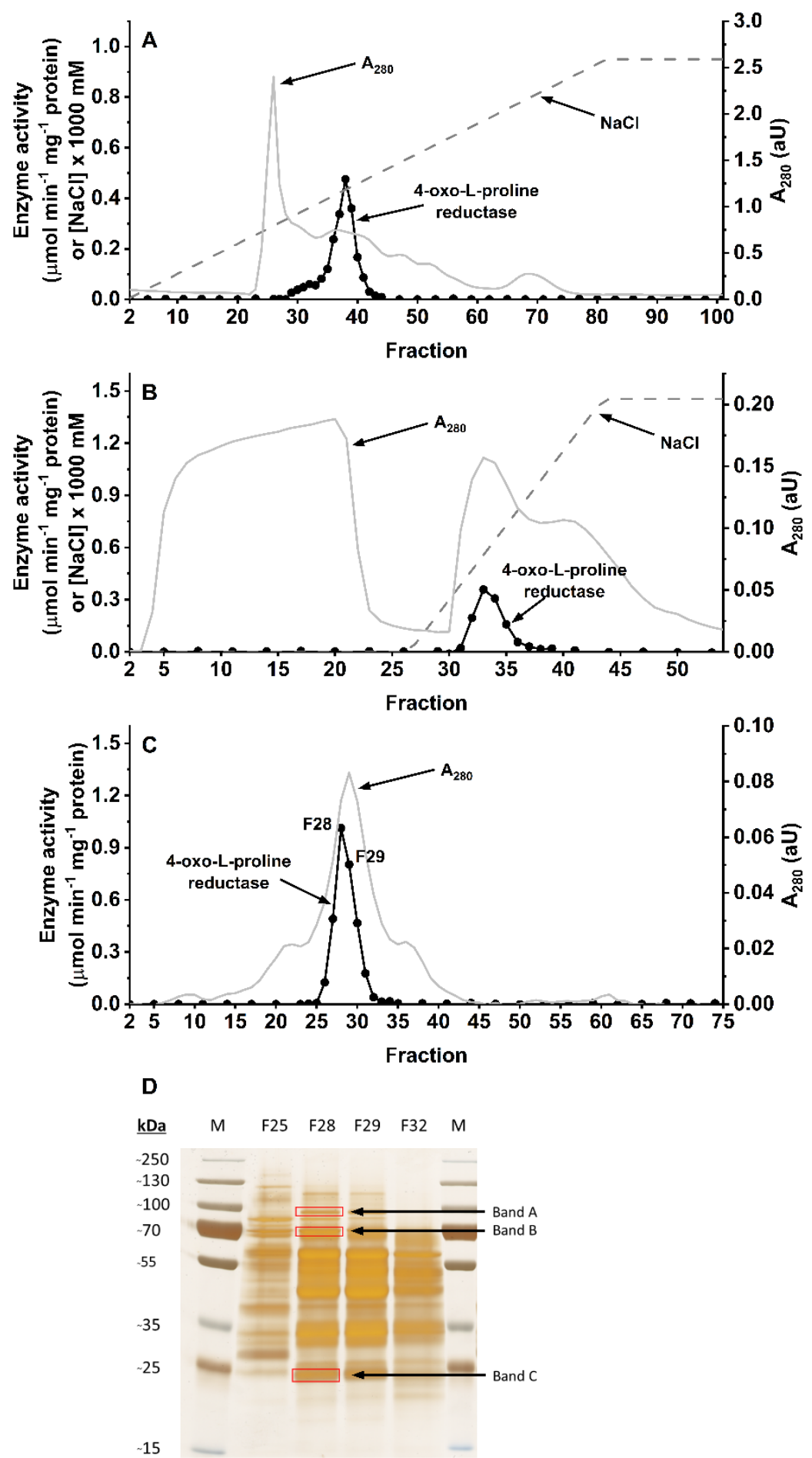

Figure 3. Purification of the rat 4-oxo-L-proline reductase. The enzyme was purified by column chromatography on A. Q Sepharose, B. HiScreen Blue FF, and C. Superdex 200 16/60 HiLoad as described in the "Experimental Procedures"section. Resulted fractions were tested for activity of 4-oxoL-proline reductase. D. The indicated fractions from Superdex 200 column were analyzed by SDS-PAGE and the gel was silver-stained (24). M, prestained protein marker. Indicated bands were cut out from the gel and analyzed by mass spectrometry. 


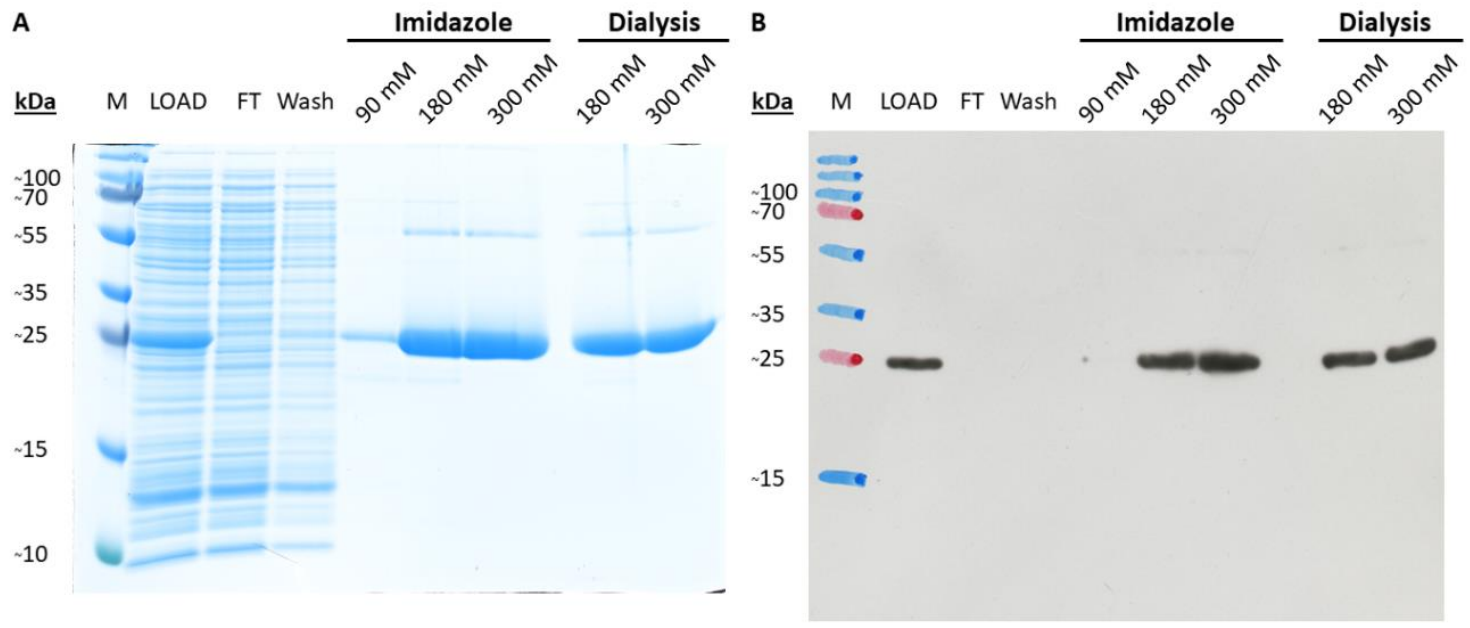

Figure 4. A. SDS-PAGE and B. Western blot analysis of recombinant rat BDH2 purification. Lysate of E.coli BL21 culture (LOAD) was applied to HisTrap ${ }^{\mathrm{TM}}$ FF Crude column and flow-through (FT) was collected. The column was washed with a buffer without imidazole (Wash). Retained proteins were eluted by applying the buffer with indicated concentrations of imidazole. To remove imidazole, fractions $180 \mathrm{mM}$ and $300 \mathrm{mM}$ were subjected to dialysis. The presence of recombinant rBDH2 protein was verified by western blot analysis using an antibody against the His 6 tag. Analogous results were obtained for human BDH2. M, prestained protein marker copied from the blotting membrane onto the film using a felt-tip pen. The purity of both recombinant proteins was above $95 \%$. 


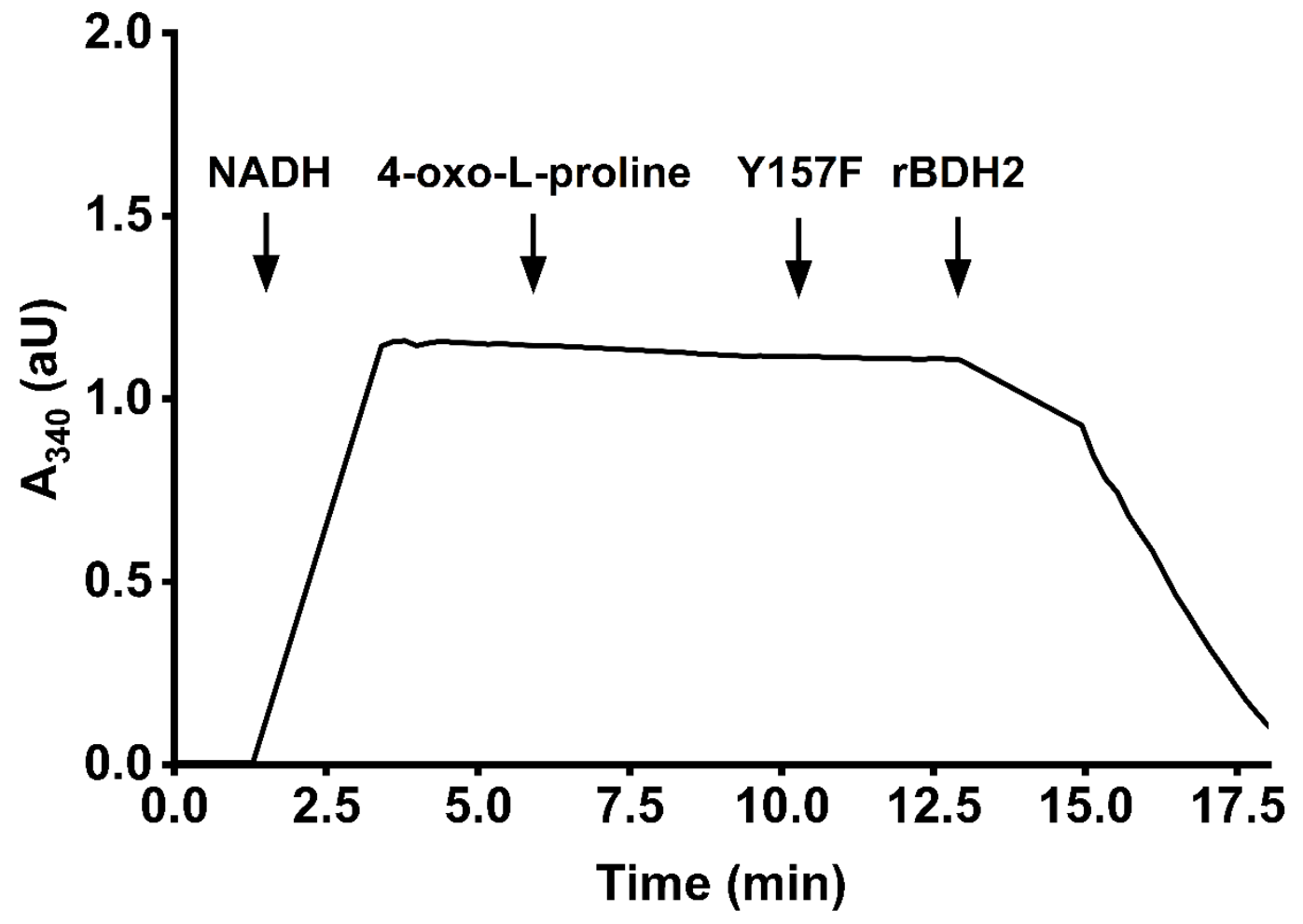

Figure 5. Test of the purified recombinant wild-type and mutated form of rat BDH2 activity (Y157F). The activity of the enzyme was followed spectrophotometrically by measuring the conversion of NADH into $\mathrm{NAD}^{+}(\lambda=340 \mathrm{~nm})$. The reaction was performed with $8 \mu \mathrm{g}$ of Y157F protein as described in the "Experimental Procedures" section. The addition of $1.8 \mu \mathrm{g}$ of the wild type rat BDH2 resulted in the complete oxidation of the NADH as indicated by the change in the absorbance $\left(\mathrm{A}_{340}\right)$. An analogous result was obtained for the mutated human form of BDH2 (Y147F). The figure shows the results of a single representative assay. 


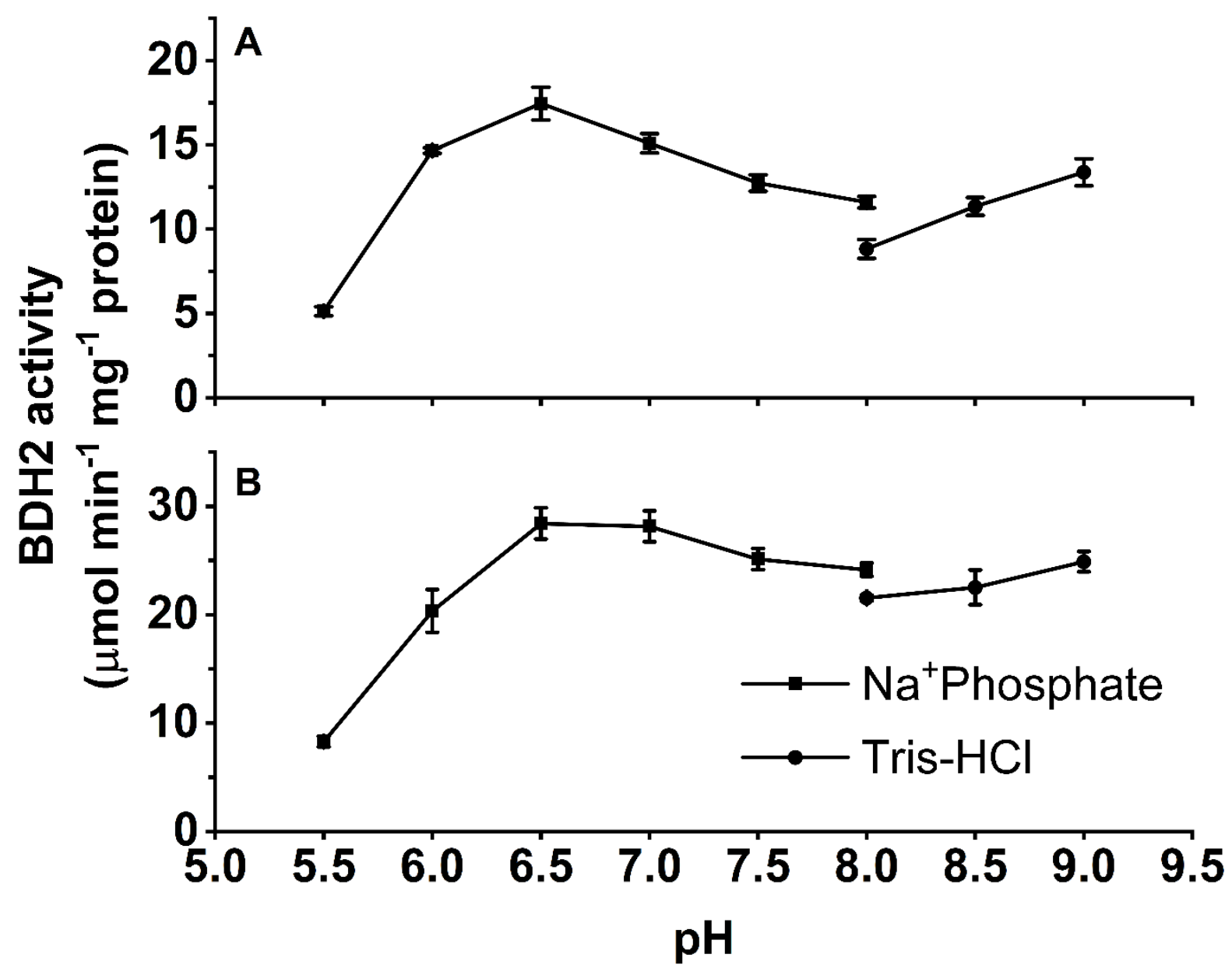

Figure 6. Effect of the $\mathrm{pH}$ on the activity of the recombinant A. rat and B. human BDH2. The reaction was performed as described in the "Experimental Procedures".. Sodium phosphate buffer was used for the lower $\mathrm{pH}$ values and Tris- $\mathrm{HCl}$ for higher $\mathrm{pH}$ values. The activity of both recombinant enzymes was slightly lower in the Tris-HCl buffer compared with sodium phosphate buffer at $\mathrm{pH}=8.0$. Values are the means \pm S.E. (error bars) of three independent experiments. When an error bar is not visible, the error is smaller than the width of the line. 

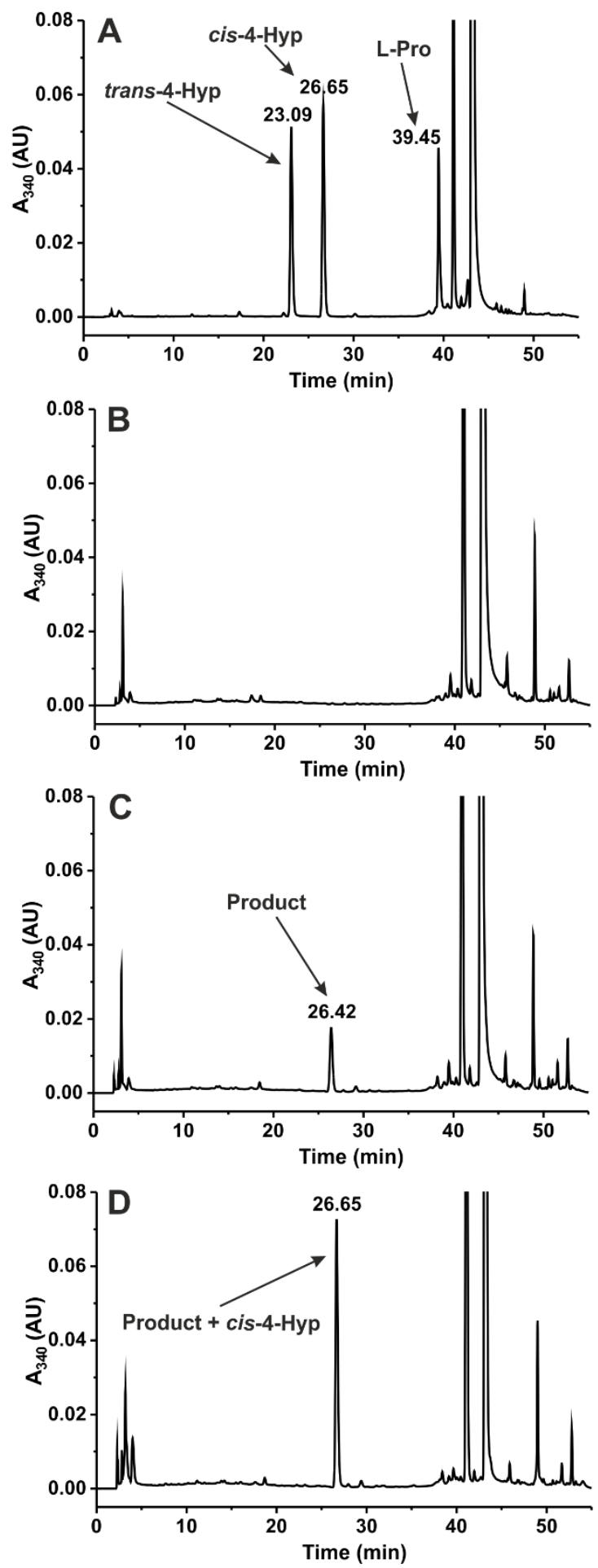

Figure 7. RP-HPLC analysis of the product formed by human BDH2 protein. Shown are chromatograms A. of standard mixture of cis-4-hydroxy-L-proline (cis-4-Hyp), trans-4-hydroxy-L-proline (trans-4-Hyp) and L-proline $(0.5 \mathrm{nmol})$ after derivatization with L-FDVA; B. of deproteinized reaction mixtures obtained during incubation of homogenous recombinant human protein $(2 \mu \mathrm{g})$ with $2 \mathrm{mM}$ 4-oxo-Lproline and $0.2 \mathrm{mM} \mathrm{NADH}$ for $0 \mathrm{~min}$ or C. $15 \mathrm{~min}$ as well as $\mathbf{D}$. following the supplementation of the former deproteinized reaction mixture with $0.5 \mathrm{nmol}$ of cis-4-hydroxy-L-proline standard. The identity of all indicated compounds was confirmed by mass spectrometry. The sample processing and chromatographic conditions are described under "Experimental Procedures". 

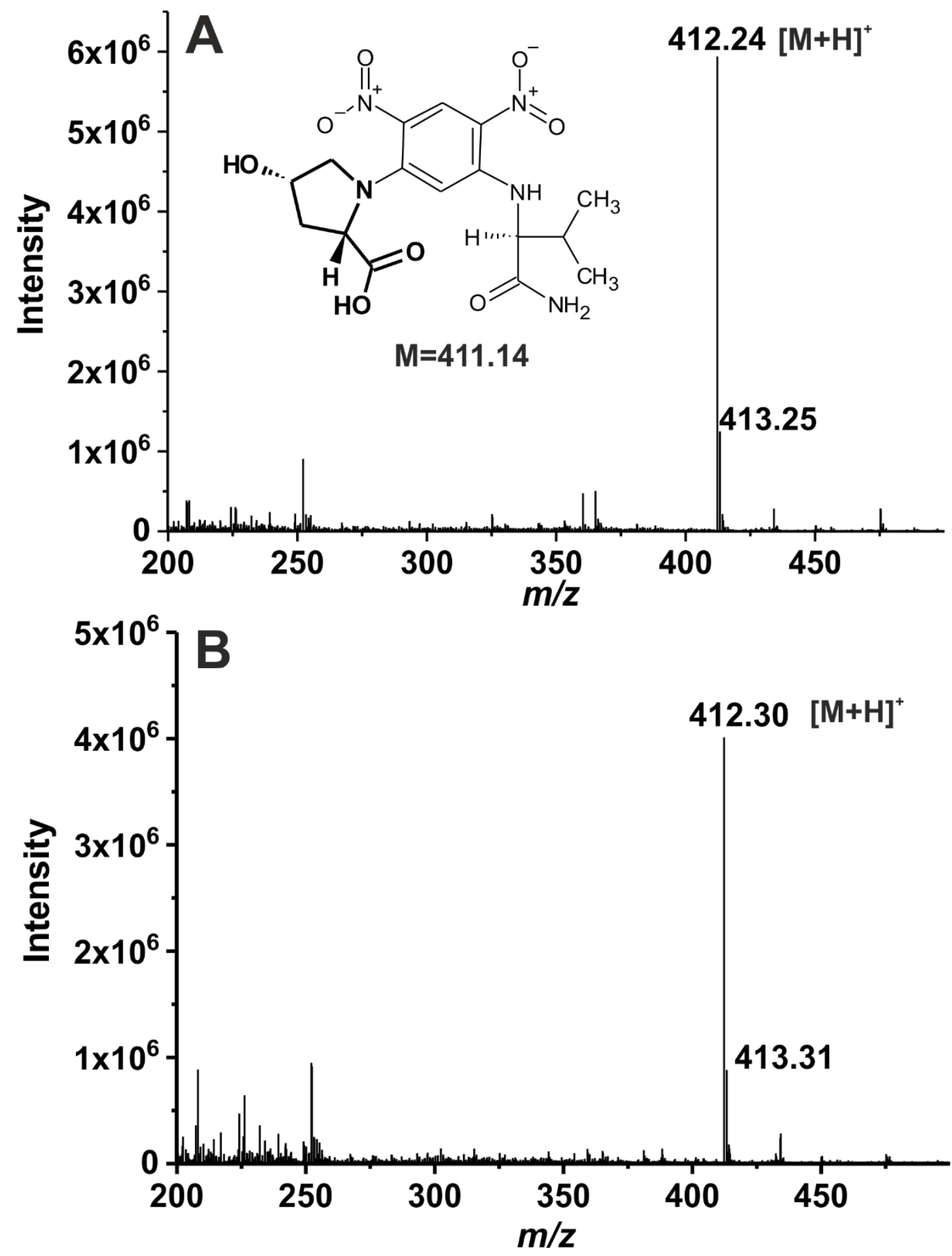

Figure 8. Quadrupole mass spectra of L-FDVA derivatives of cis-4-hydroxy-L-proline and the product formed by human $\mathrm{BDH} 2$ protein. The homogenous recombinant human enzyme was incubated for 15 min with $2 \mathrm{mM}$ 4-oxo-L-proline and $0.2 \mathrm{mM} \mathrm{NADH}$, and the progress of the reaction was followed spectrophotometrically at $\lambda=340 \mathrm{~nm}$. The product was then derivatized with L-FDVA, chromatographed on a reversed-phase C18 column, and analyzed by mass spectrometry. Mass spectra, covering the mass range $m / z$ 200-500, A. of commercial cis-4-hydroxy-L-proline derivatized with L-FDVA and B. the product generated by human $\mathrm{BDH} 2$ enzyme were acquired. The structure of the L-FDVA derivative of cis-4-hydroxy-L-proline (in bold) is also shown. 


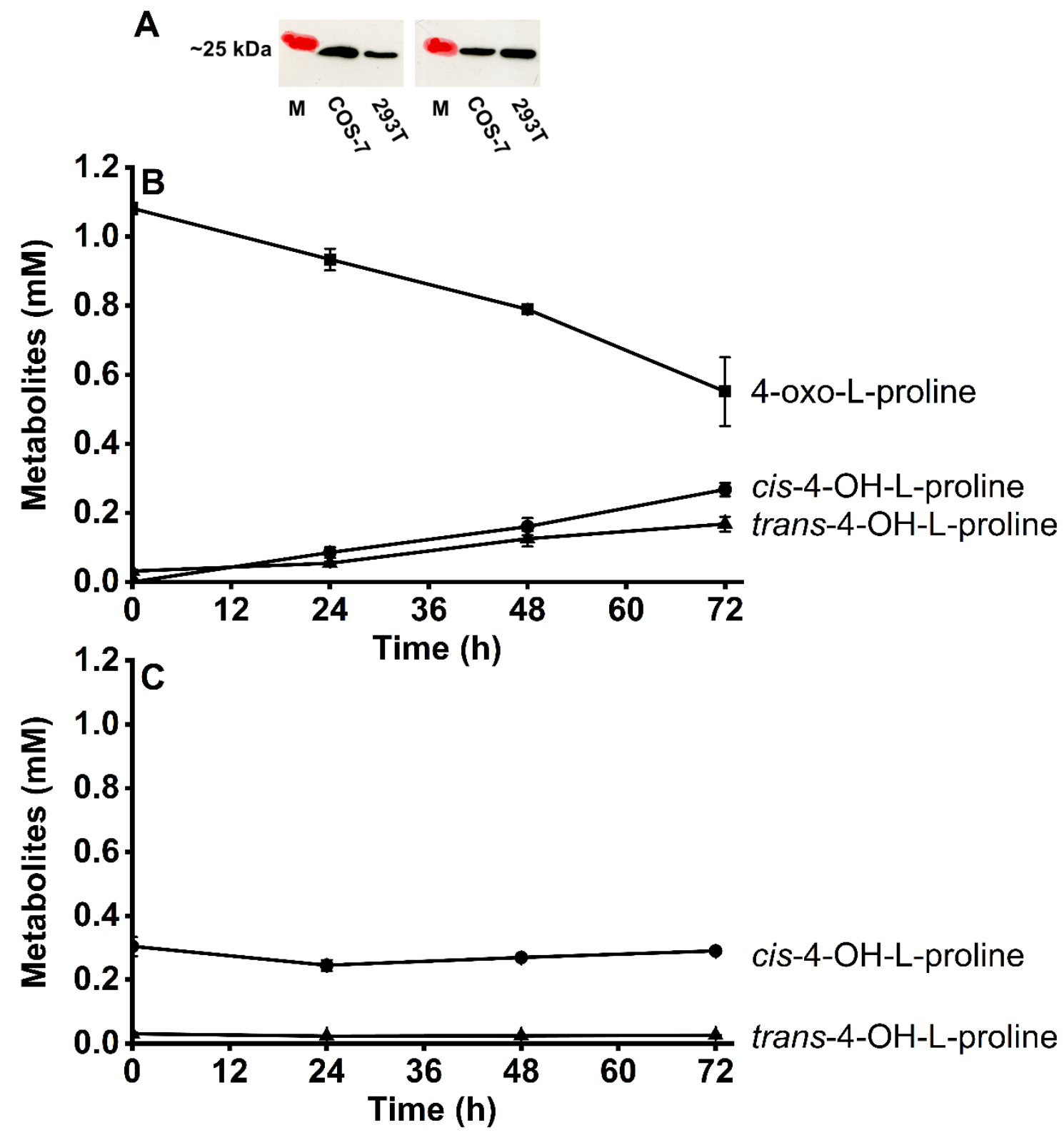

Figure 9. Metabolism of 4-oxo-L-proline and cis-4-hydroxy-L-proline in HEK293T cells. A. Western blot analysis of HEK293T and COS7 cell extracts from two different passages, showing the endogenous expression of $\mathrm{BDH} 2$. The analysis was performed using $30 \mu \mathrm{g}$ of total protein with a polyclonal rabbit antibody against human BDH2. M, prestained protein marker copied from the blotting membrane onto the film using a felt-tip pen; B. Changes in the extracellular concentration of 4-oxo-L-proline and its metabolites in HEK293T cells, following supplementation of the cell culture medium with $1 \mathrm{mM} 4$-oxoL-proline. C. Changes in the extracellular concentration of trans- and cis-4-hydroxy-L-proline in HEK293T cells, following supplementation of the cell culture medium with $0.3 \mathrm{mM}$ cis-4-hydroxy-Lproline. The cells were plated in 6-well dishes and grown for $24 \mathrm{~h}$. After that time, the cell culture medium was supplemented with the indicated amino acids, and the incubation was continued for up to $72 \mathrm{~h}$ as described under "Experimental Procedures". Values are the means \pm S.E. (error bars) of three independent experiments performed with cells from three different culture passages $(n=3)$. When no error bar is shown, the error is smaller than the width of the line. 


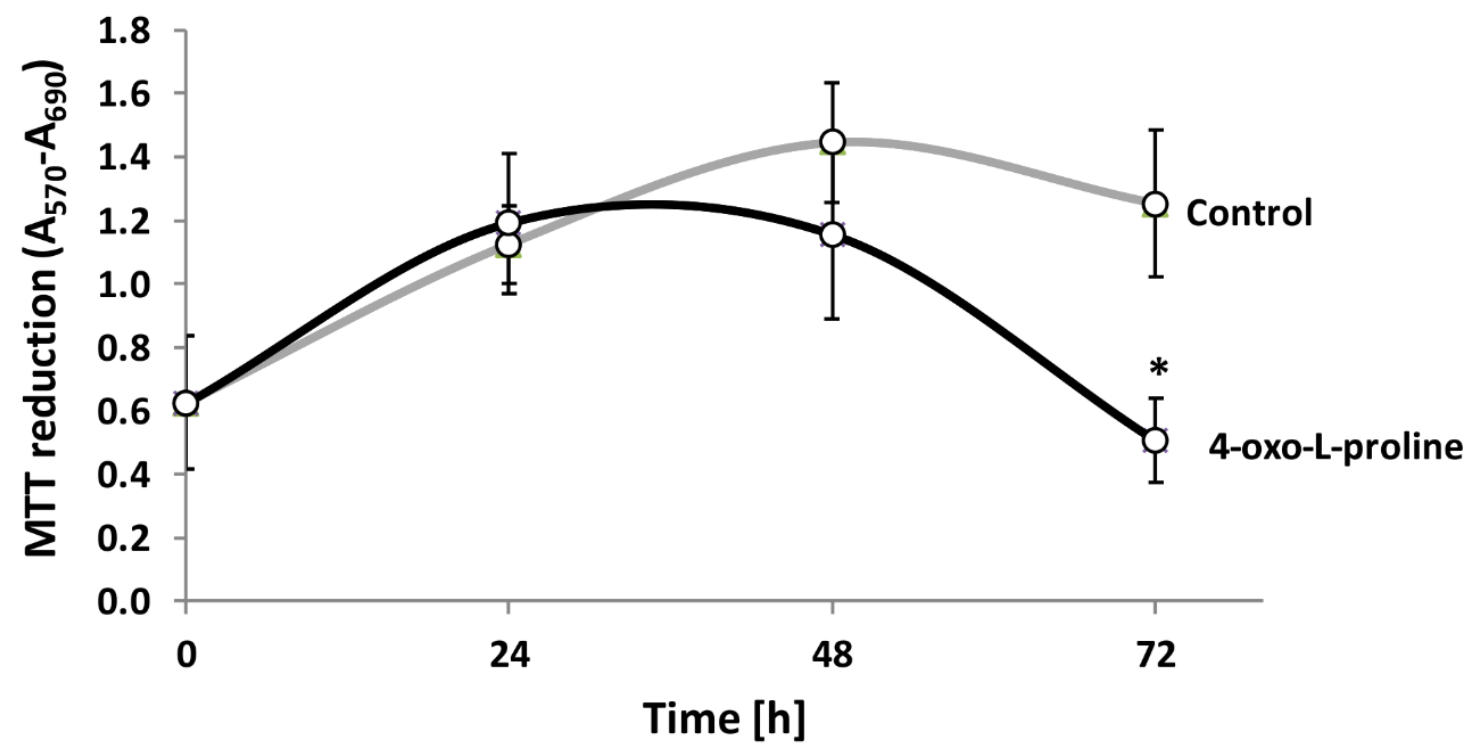

Figure 10. The cell viability of HEK293T cells in the presence of 4-oxo-L-proline. Cell viability was tested at the indicated time points by the MTT assay. The cells were seeded in 12-well dishes and grown for $24 \mathrm{~h}$. After that time, the cell culture medium was replaced with the fresh one supplemented with $1 \mathrm{mM} 4$-oxo-L-proline, and the incubation was continued for up to $72 \mathrm{~h}$ as described under "Experimental Procedures". Values are the means \pm S.E. (error bars) of three independent experiments performed in triplicates with cells from three different culture passages $(n=3)$. The data were assumed to be distributed normally. Statistical significance was analyzed using a one-tailed paired Student's $t$-test. " $p<0.02$. 